\title{
Self-perception, knowledge, and awareness of halitosis among female university students
}

This article was published in the following Dove Press journal:

Clinical, Cosmetic and Investigational Dentistry

26 May 2017

Number of times this article has been viewed

\author{
Azizah Bin Mubayrik' \\ Rana Al Hamdan² \\ Emad M Al Hadlaq' \\ Hamad AlBagieh' \\ Dan AlAhmed ${ }^{3}$ \\ Hend Jaddoh ${ }^{3}$ \\ Mawadh Demyati ${ }^{3}$ \\ Rawan Abu Shryei ${ }^{3}$ \\ 'Oral Medicine and Diagnostic \\ Science Department, ${ }^{2}$ Restorative \\ Dental Science Department, ${ }^{3}$ Interns, \\ College of Dentistry, King Saud \\ University, Riyadh, Saudi Arabia
}

Background: Halitosis or oral malodor is defined as an unpleasant breath odor. It can become a serious problem affecting individuals' social communication and self-confidence. Furthermore, it is a discomforting issue for the people around the person affected, because they consider it embarrassing to inform the person of the problem.

Aim: This study was designed to measure self-perception, knowledge, and awareness of halitosis among female university students in Saudi Arabia.

Materials and methods: A cross-sectional survey was implemented with 392 volunteer participants who responded to a questionnaire on their self-perception, knowledge, and awareness of halitosis.

Results: The response rate was $89.1 \%$ (392/440). Self-perception of halitosis was low $(21.4 \%)$, whereas a larger percentage $(78.1 \%)$ indicated noticing people with bad breath. Most participants $(80.4 \%)$ thought that the gastrointestinal tract is the primary source of halitosis. Seventy-seven percent preferred using personal methods such as mouthwash and chewing gum to treat oral malodor. According to $82.1 \%$ of respondents, a dentist is the most appropriate professional to treat halitosis. Conclusion: The investigation revealed low self-perception and limited knowledge regarding halitosis. Therefore, the role of dentists in informing and educating their patients concerning oral malodor should be enhanced. Public education about the causes of and possible ways of managing bad breath should be increased.

Keywords: halitosis, female, self-perception, awareness

\section{Introduction}

Halitosis or oral malodor is an unpleasant breath odor that interferes with self-confidence and with people's professional and social life. ${ }^{1-3}$ It can have both extraoral and intraoral causes. The main substance responsible for this malodor is the volatile sulfur compounds (VSCs) produced from protein degradation by gram-negative anaerobic bacteria. ${ }^{2,4-6}$ The most commonly identified substances involved are methyl mercaptan and hydrogen sulfide. ${ }^{5,6}$ Halitosis has been associated with plaque, dental diseases, and tongue coating. ${ }^{2,5-6}$ It can be classified into several categories: genuine halitosis, which can be physiological or pathological; pseudohalitosis, in which patients think they have bad breath even though they actually do not; and halitophobia, in which people continue to fear that they have bad breath after halitosis treatment. ${ }^{7-11}$ Common etiologies of bad breath include periodontal diseases, tongue coating, caries, and decreased salivary flow. ${ }^{12-14}$ Extraoral causes comprise medication use, psychological factors, and pathologies related to the nose, tonsils, lungs, and stomach. ${ }^{5,6,14-16}$ Treatment options,
Correspondence: Azizah Bin Mubayrik Oral Medicine and Diagnostic Science Department, College of Dentistry, King Saud University, 3680 - King Saud University Unit No 3ar Riyadh 12372 7453 Kingdom of Saudi Arabia Email aalmobeirik@ksu.edu.sa 
depending on the patient's needs, may be provided by dentists, physicians, psychologists, or psychiatrists.

The importance of halitosis is heavily related to its psychological and social impact. Bad breath has been associated with psychiatric symptoms such as phobias, depression, considerable worry, and changes in behavior and can adversely affect self-esteem, self-confidence, and impact on social participation. ${ }^{15,17-21}$

The impact of halitosis is especially strong among younger people. ${ }^{22}$ Several studies have addressed selfperceived halitosis (SPH) among youth, but their samples included only dental students. ${ }^{23-27}$ To the best of our knowledge, only one study, in Libya, has addressed the problem among a broader population of young people. ${ }^{28}$

The objective of the present study was to evaluate selfperception, knowledge, and awareness of oral malodor among female students at King Saud University, Riyadh, Saudi Arabia, which is the country's oldest and largest public university.

\section{Materials and methods}

A cross-sectional study was implemented with a randomly selected sample. Self-administered questionnaires were distributed anonymously to 440 students from various majors in classrooms and gathering areas of King Saud University's female campus. The purpose of the study was explained, and any questions raised were addressed. Of the 440 young women who received the questionnaire, 392 completed it and 48 withdrew from the study due to lack of time. changes were required as a result. of oral malodor. 22.0; IBM Corp, Armonk, NY).

\section{Ethical considerations}

\section{Results}

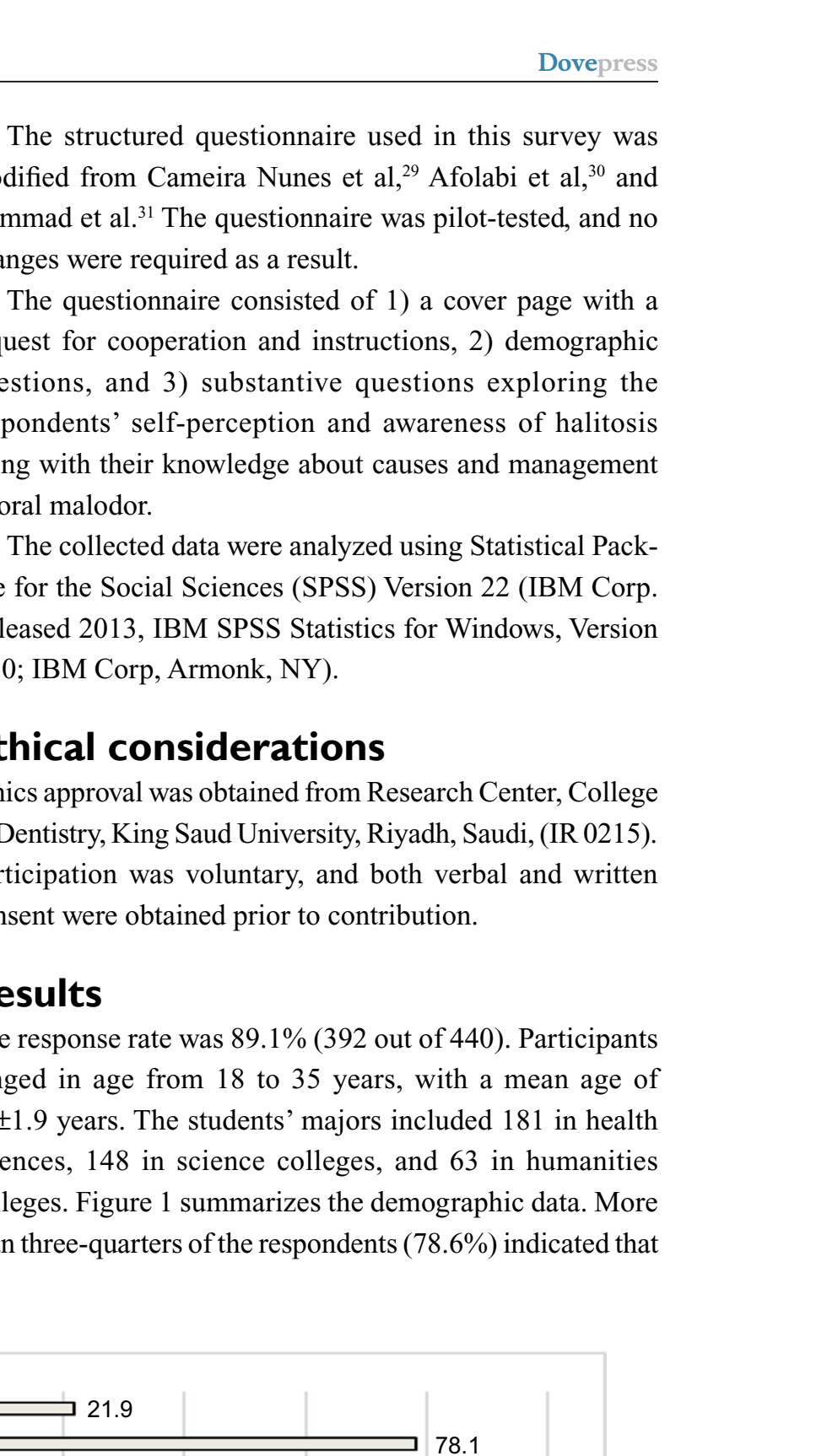

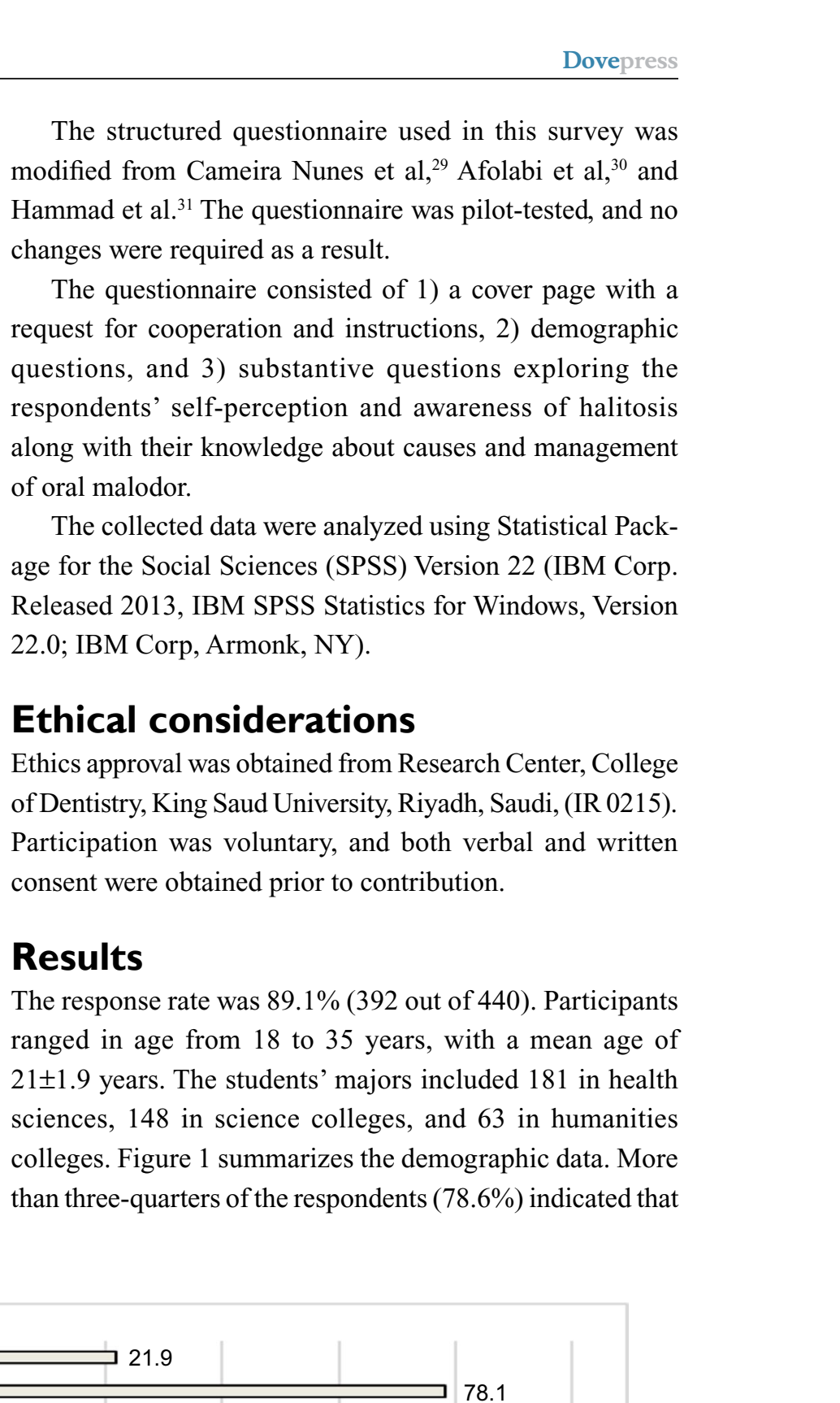

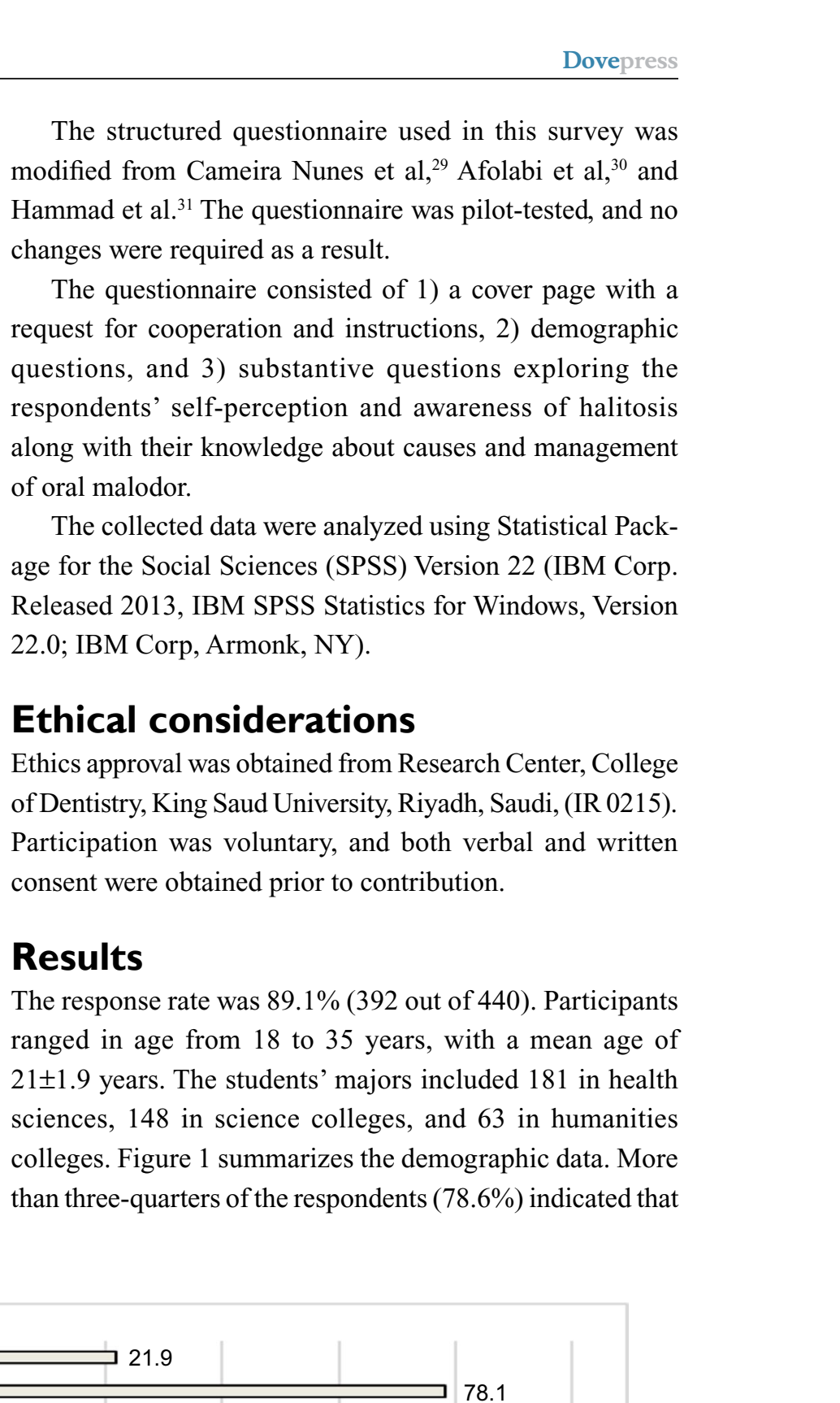

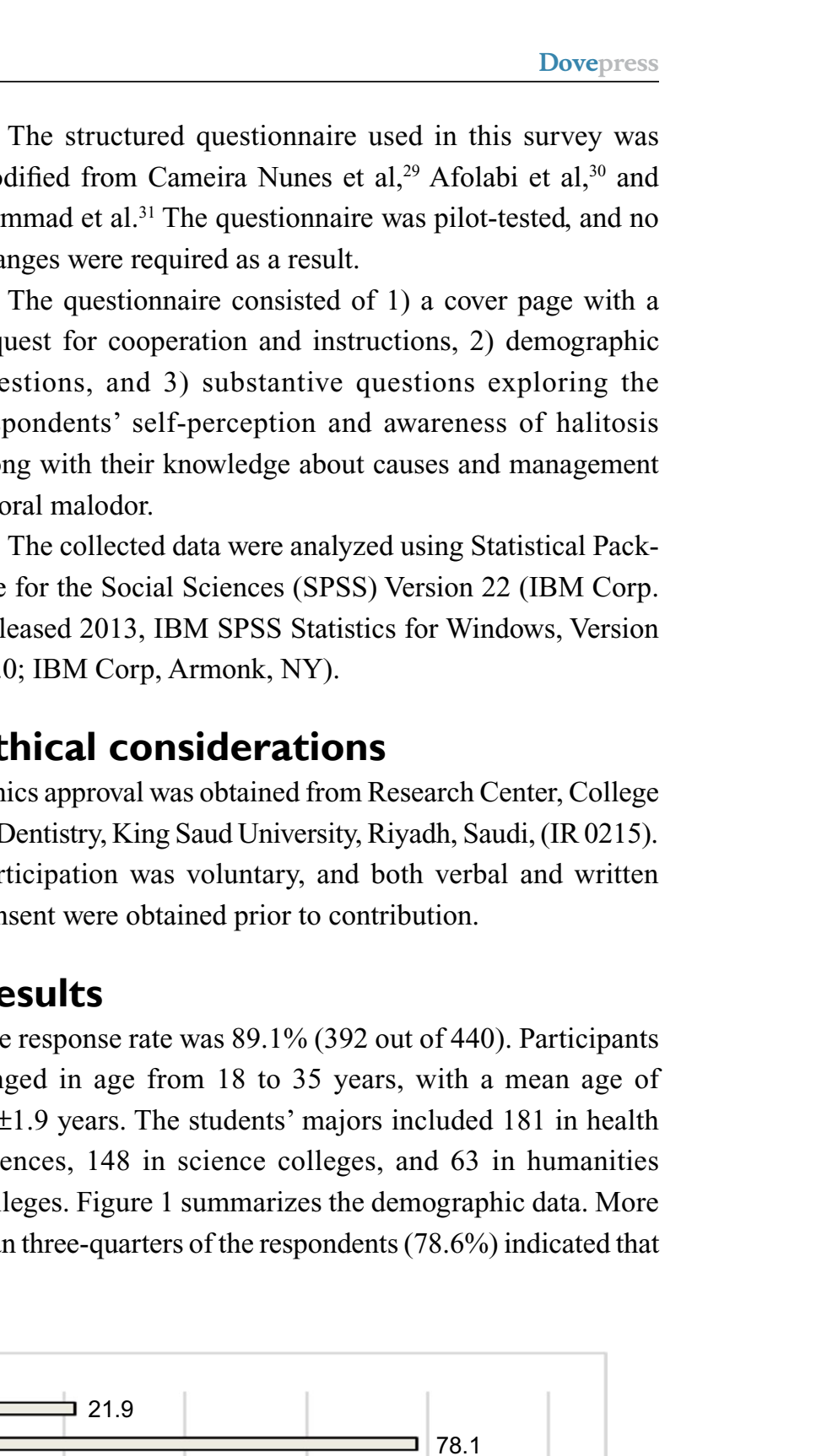

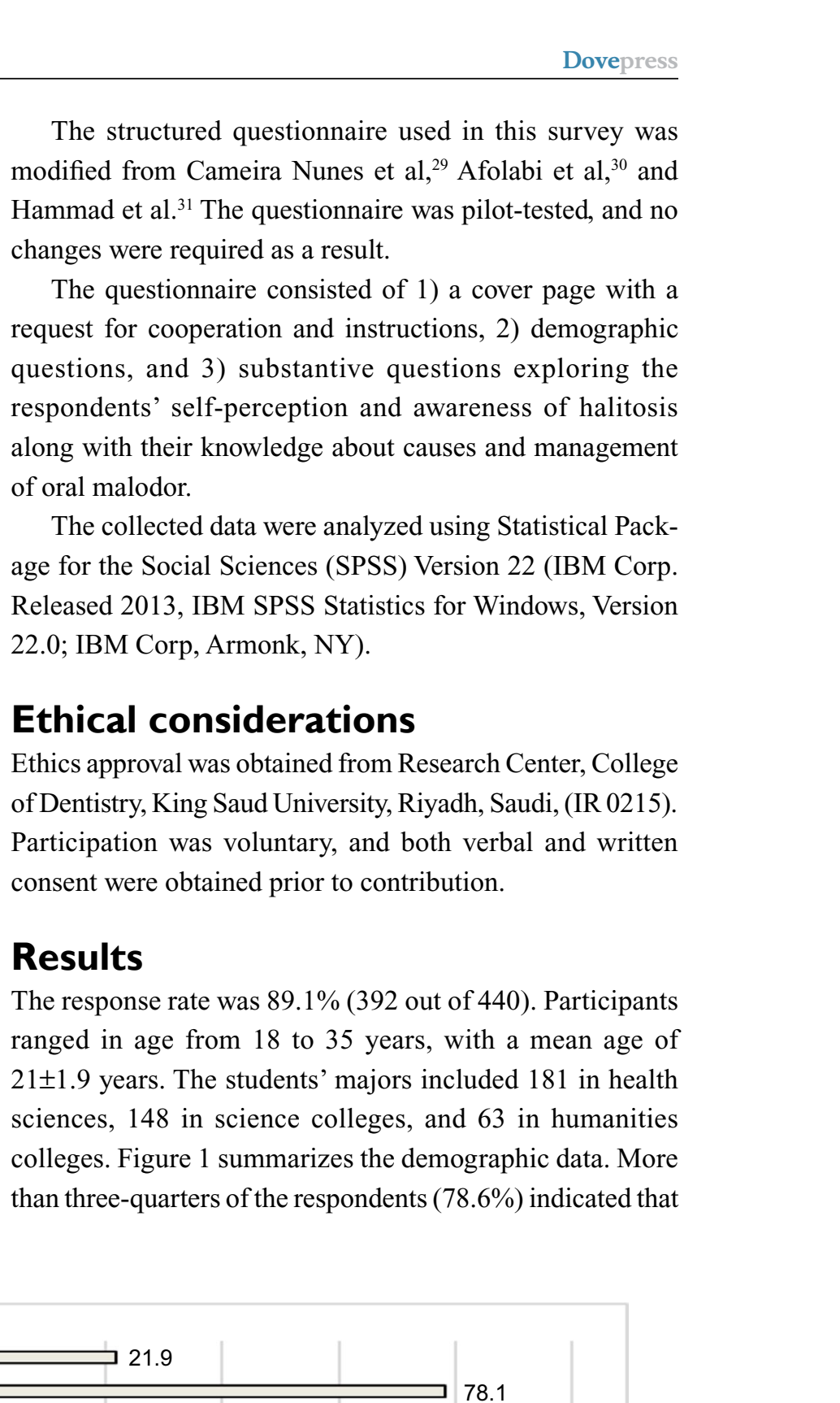

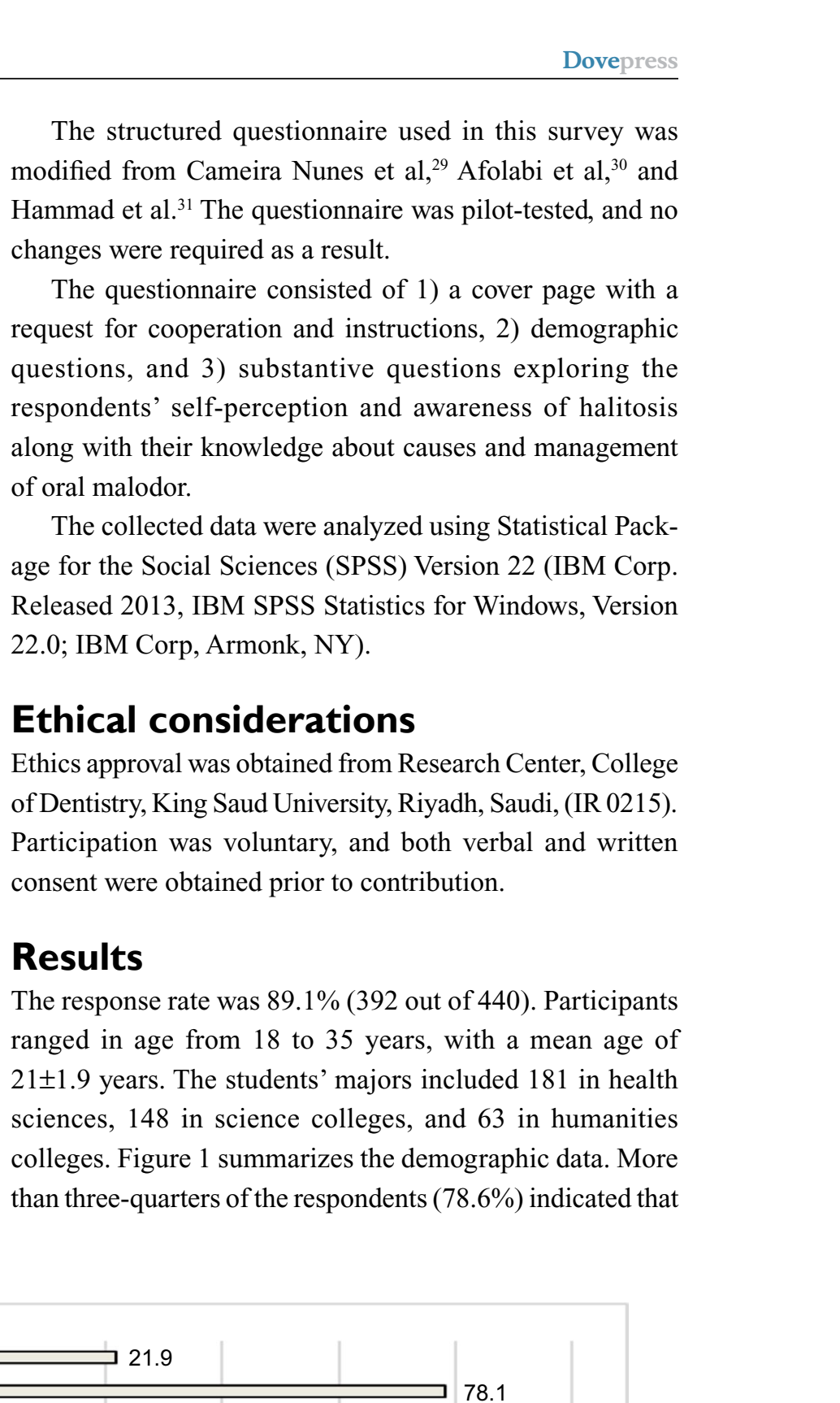

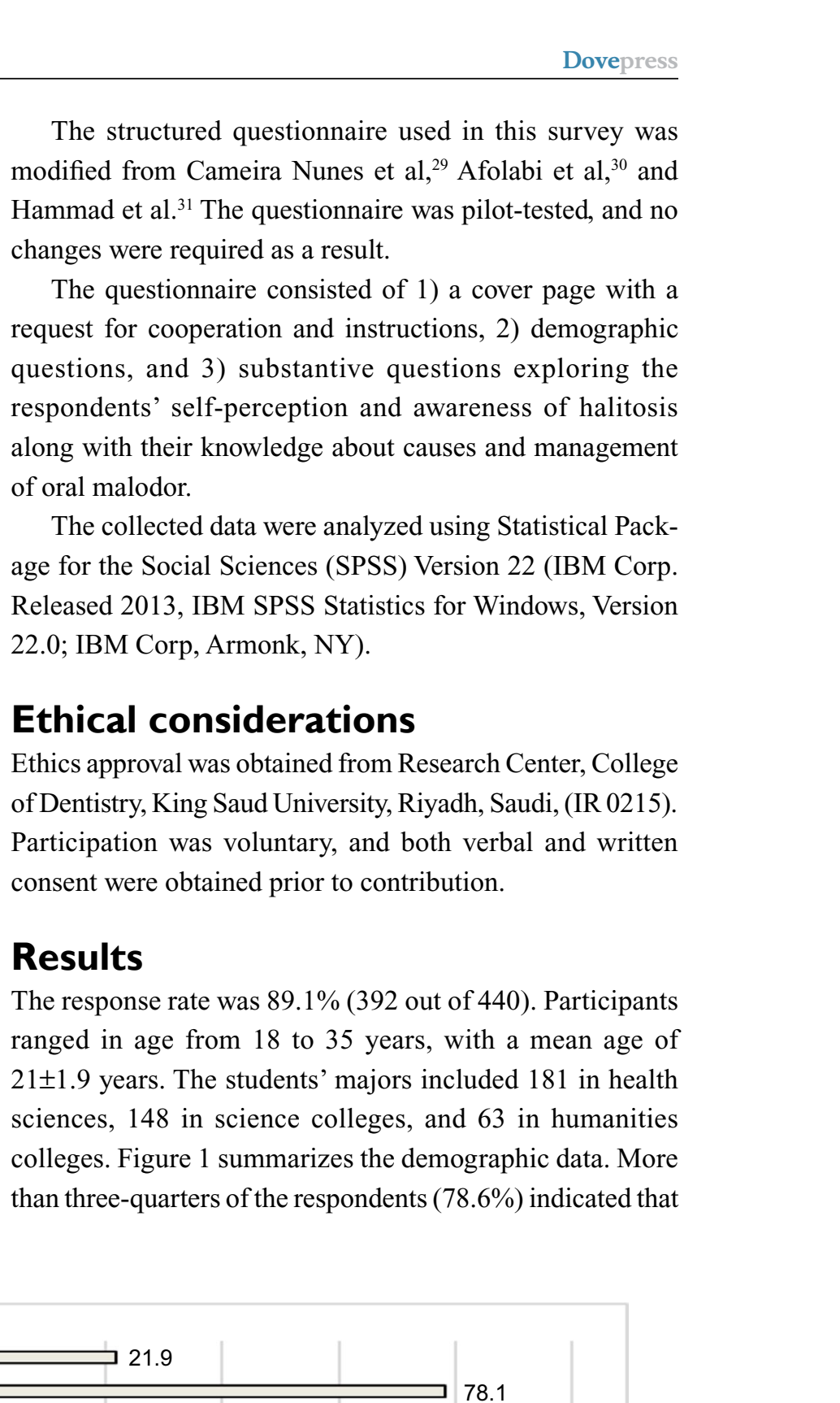

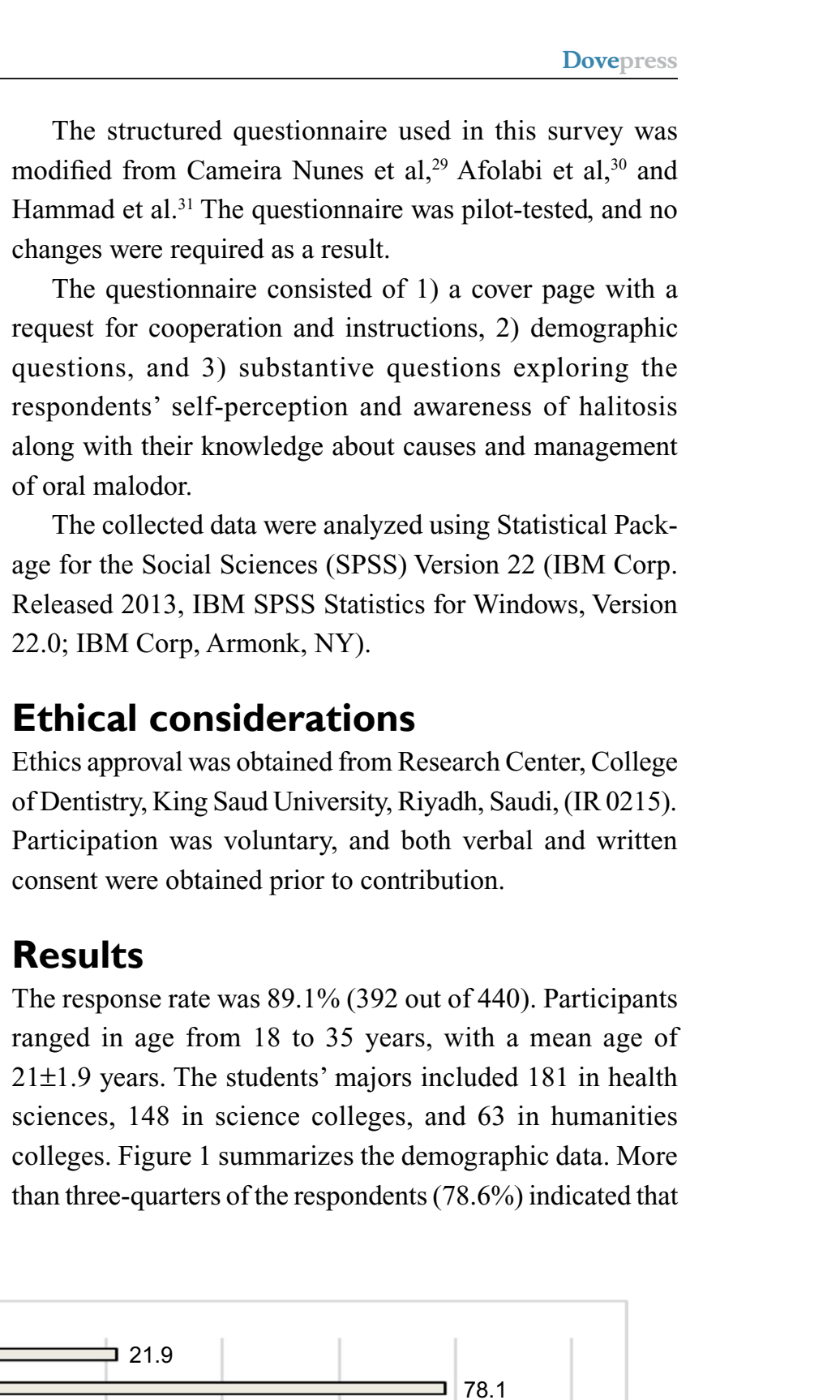

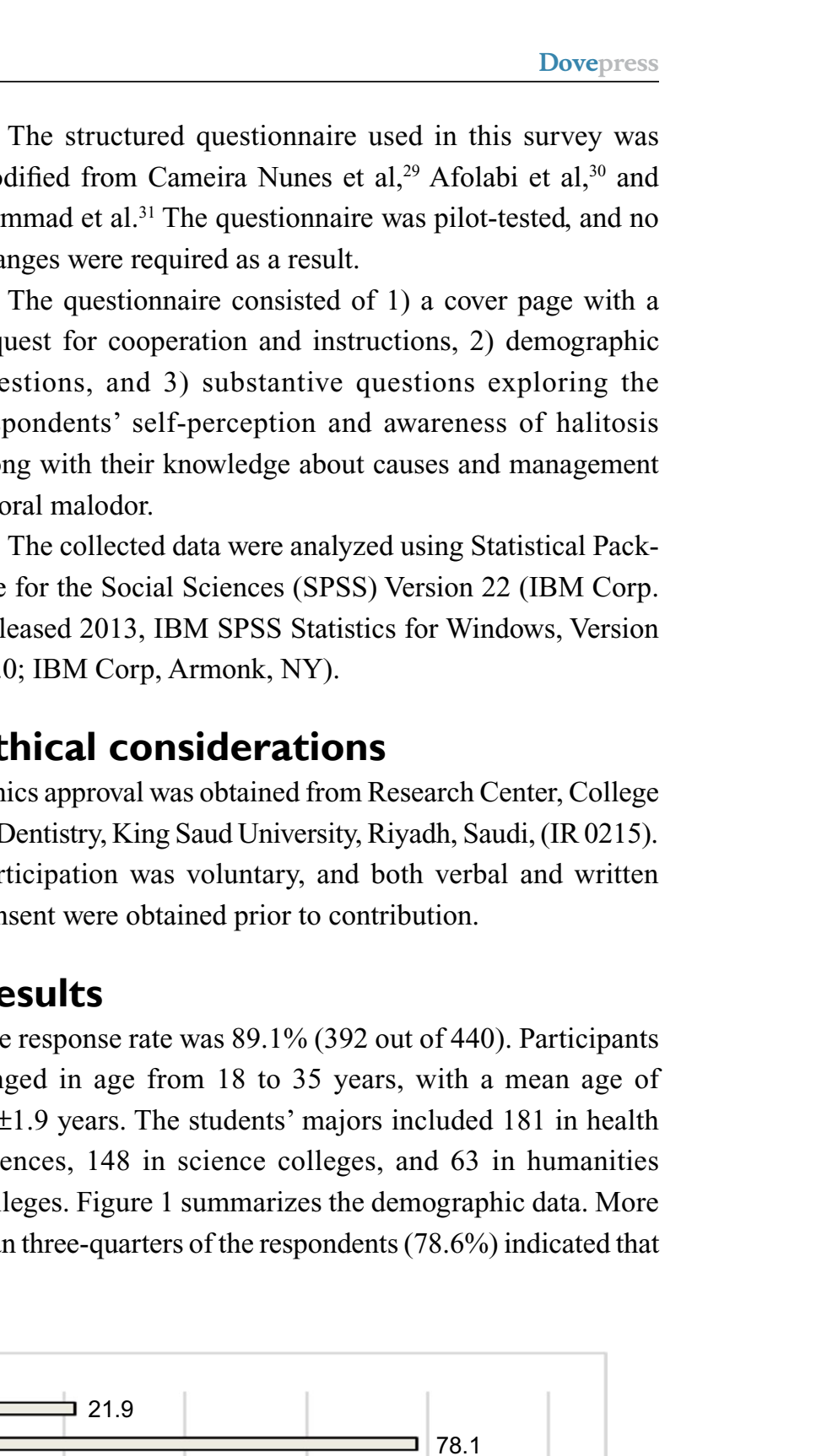

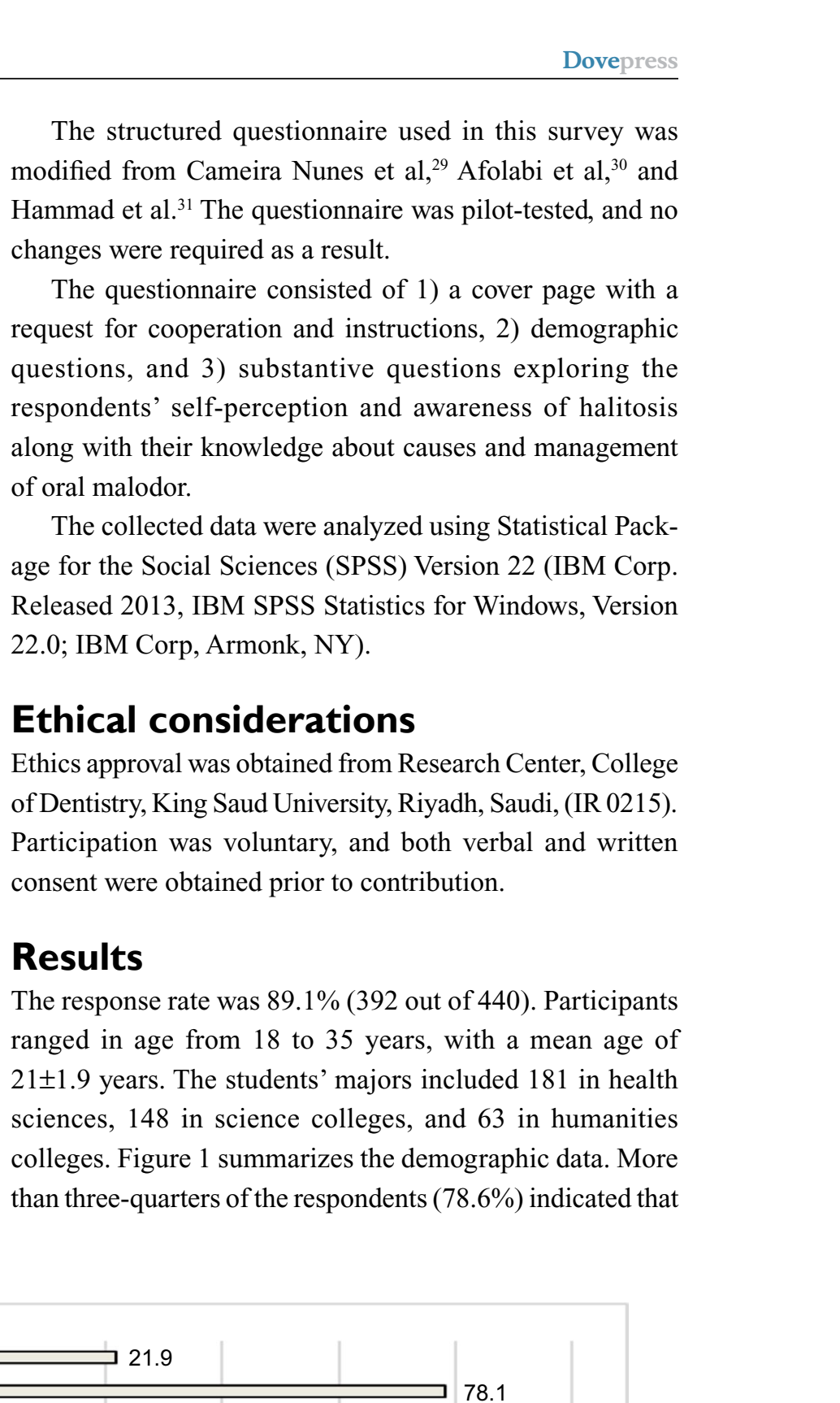

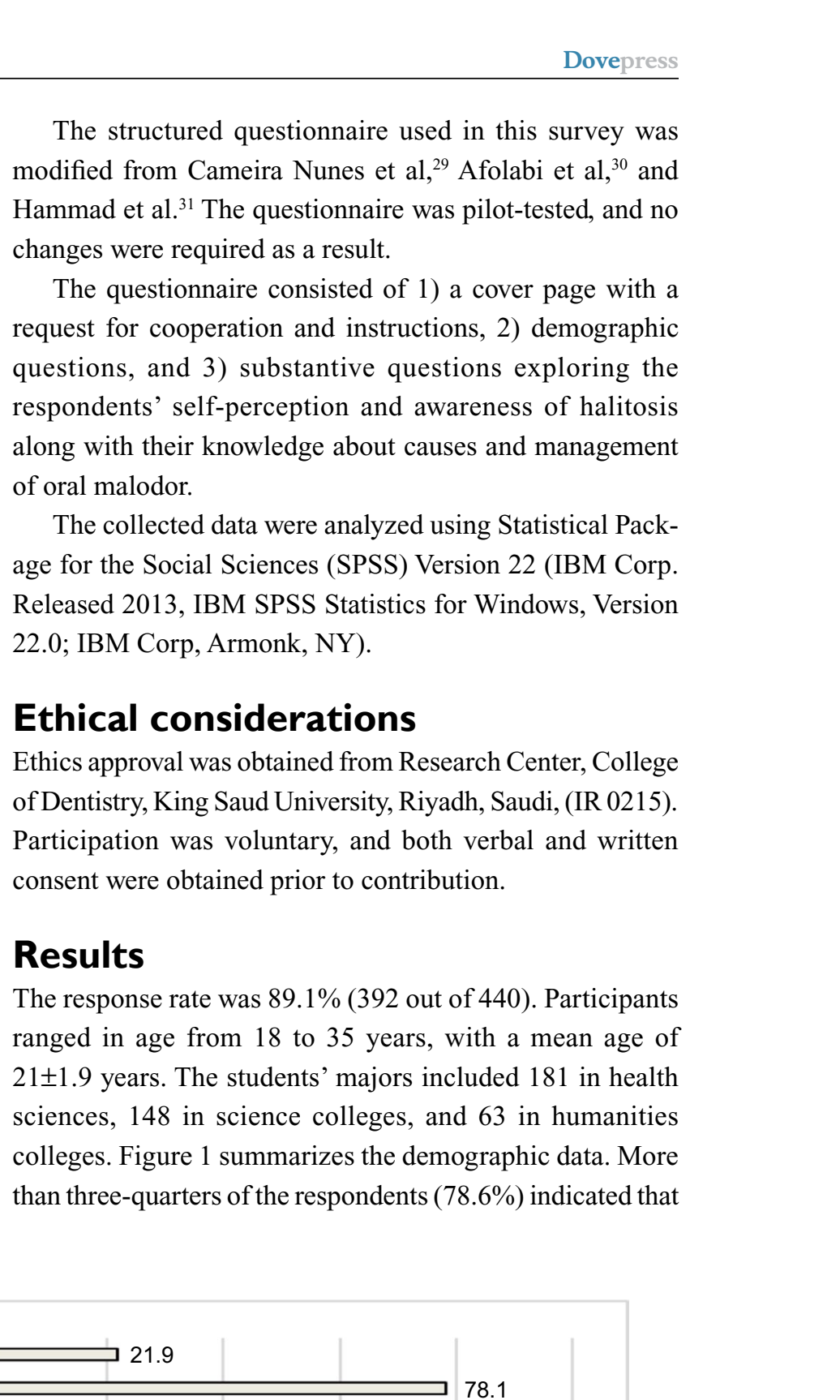

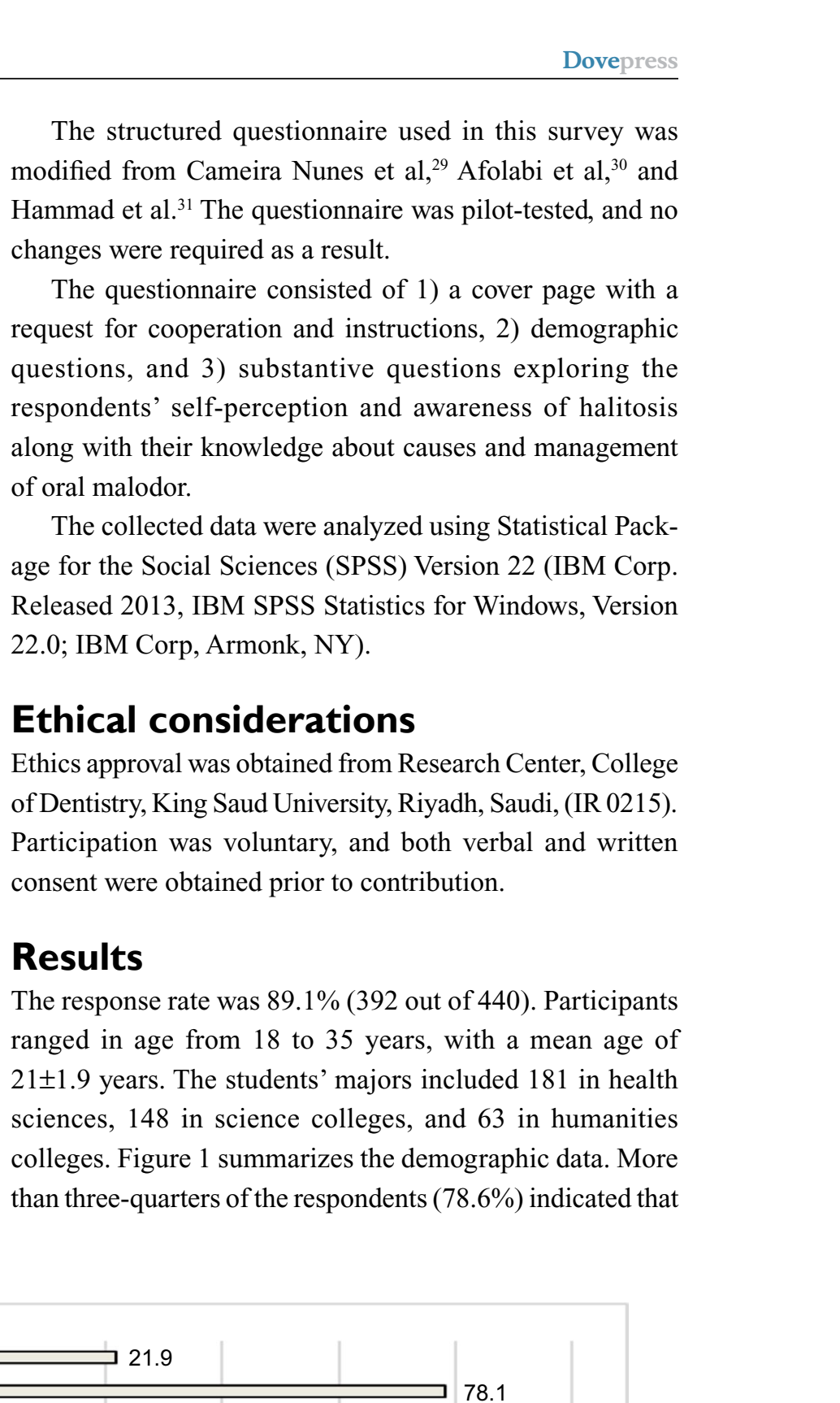

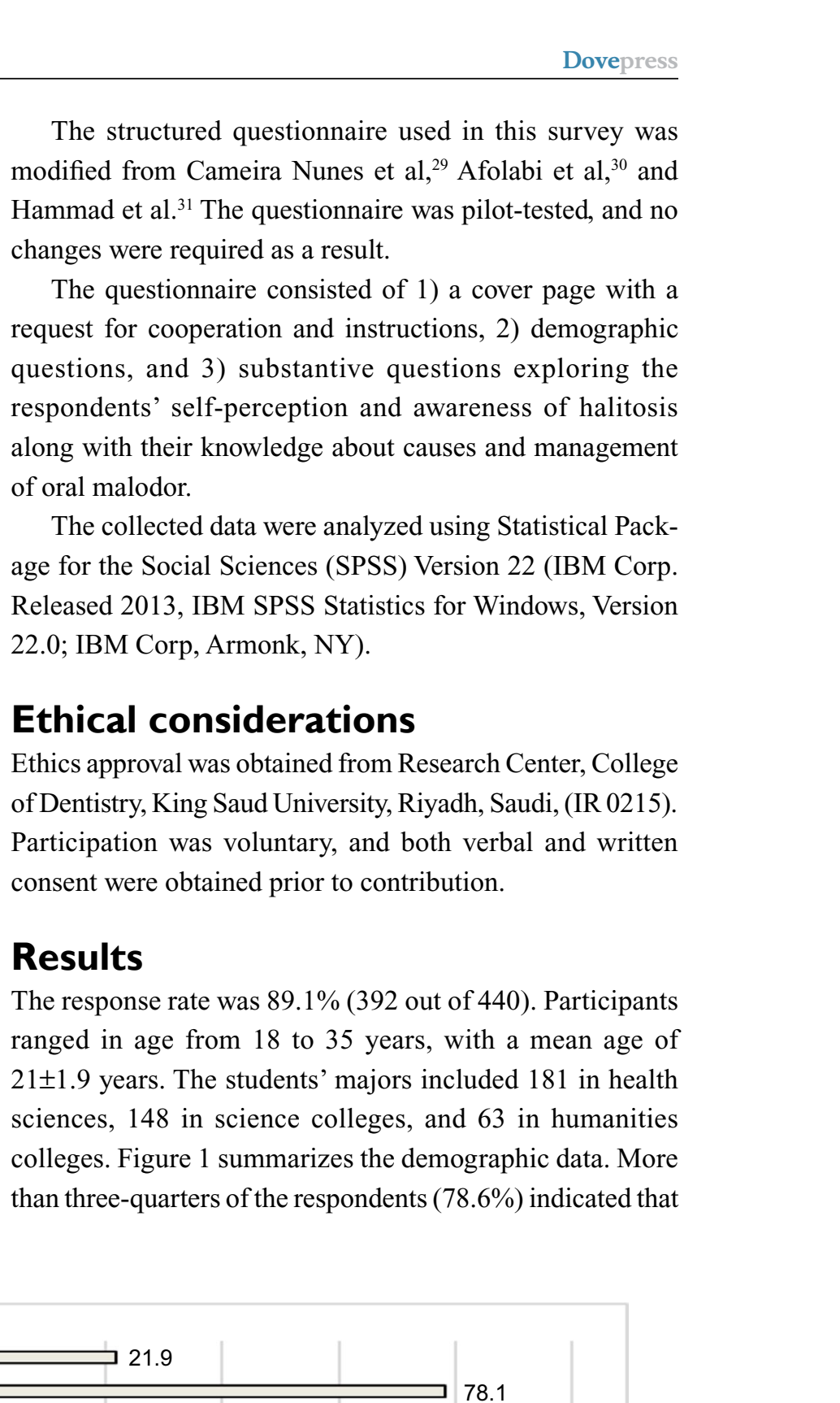

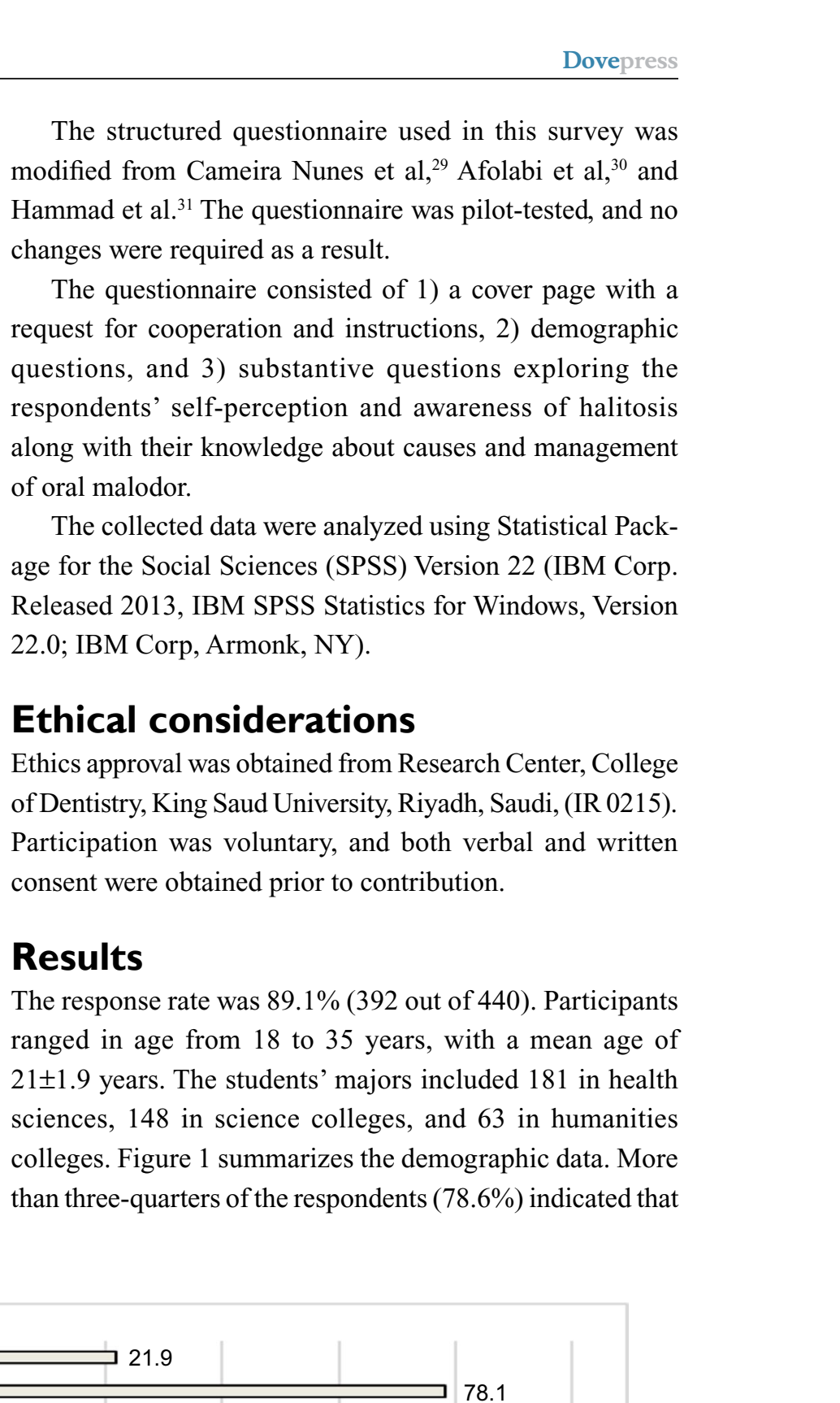

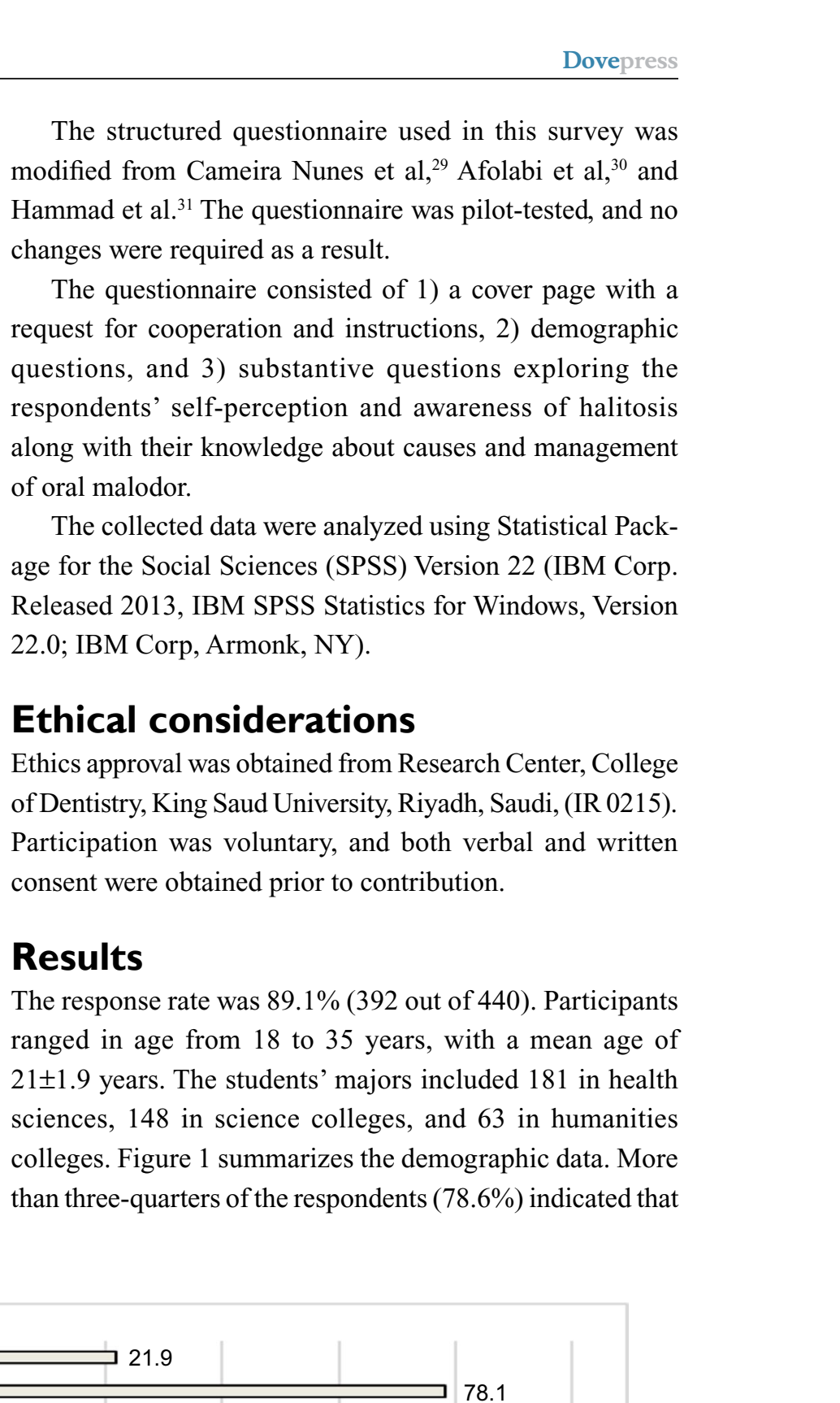

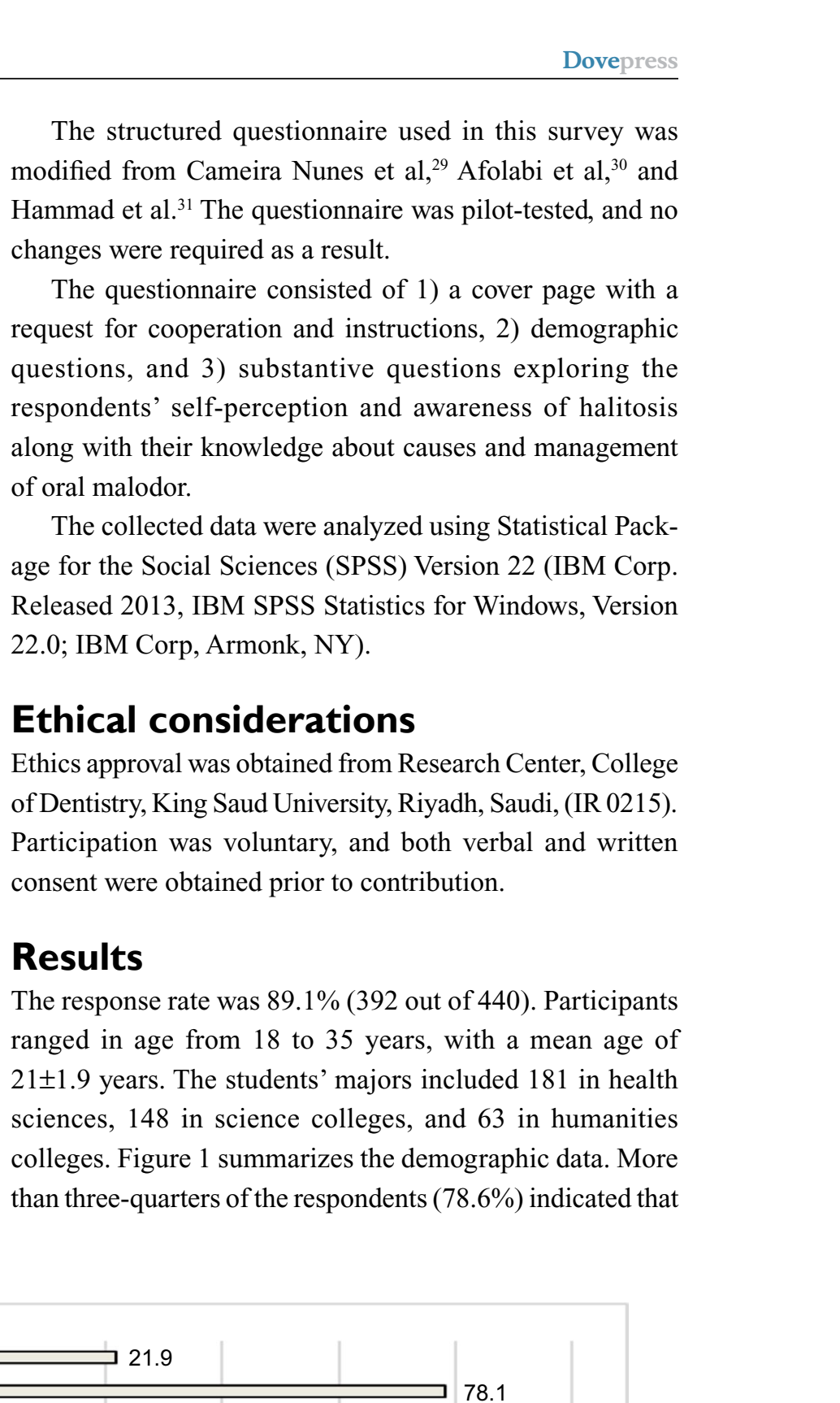

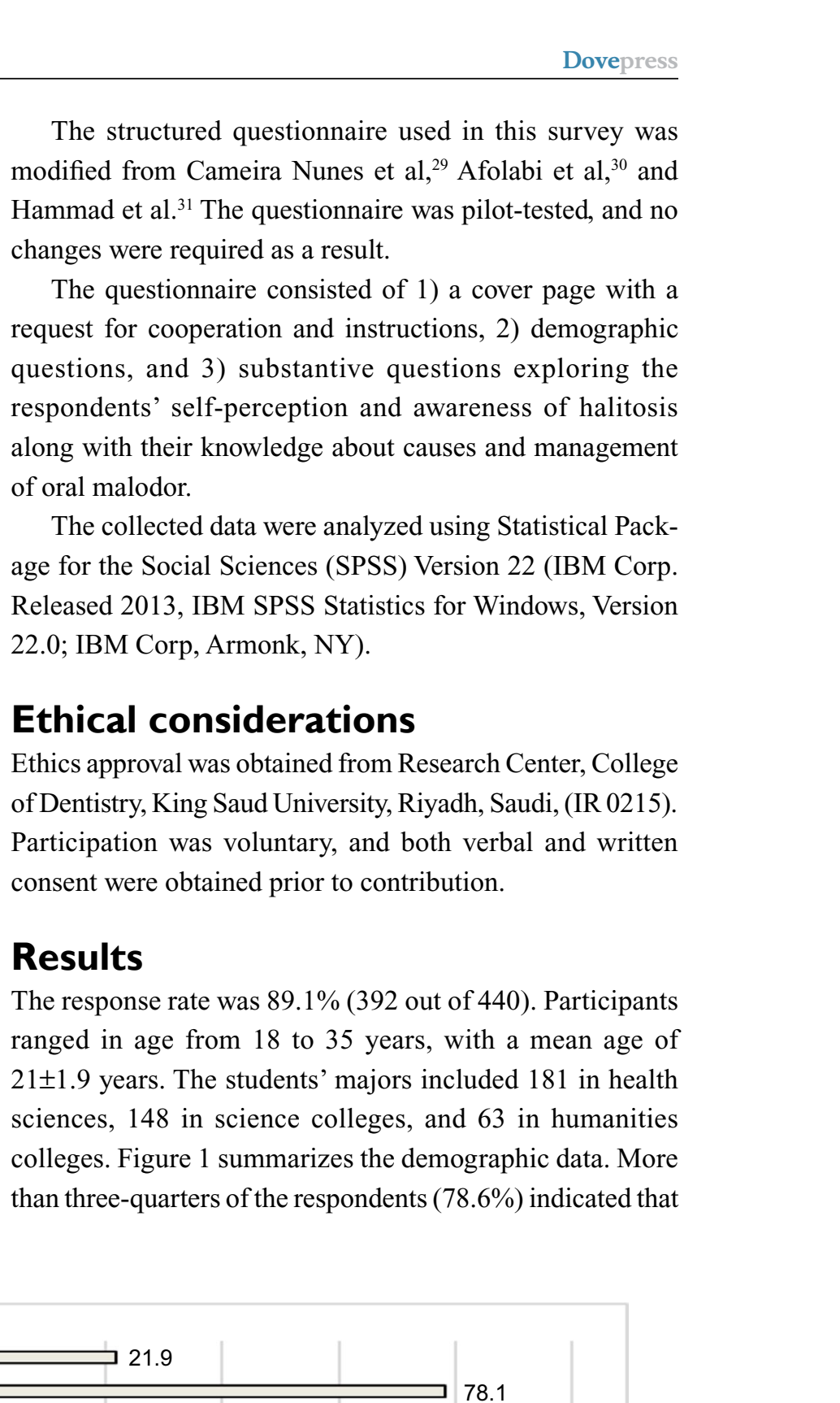

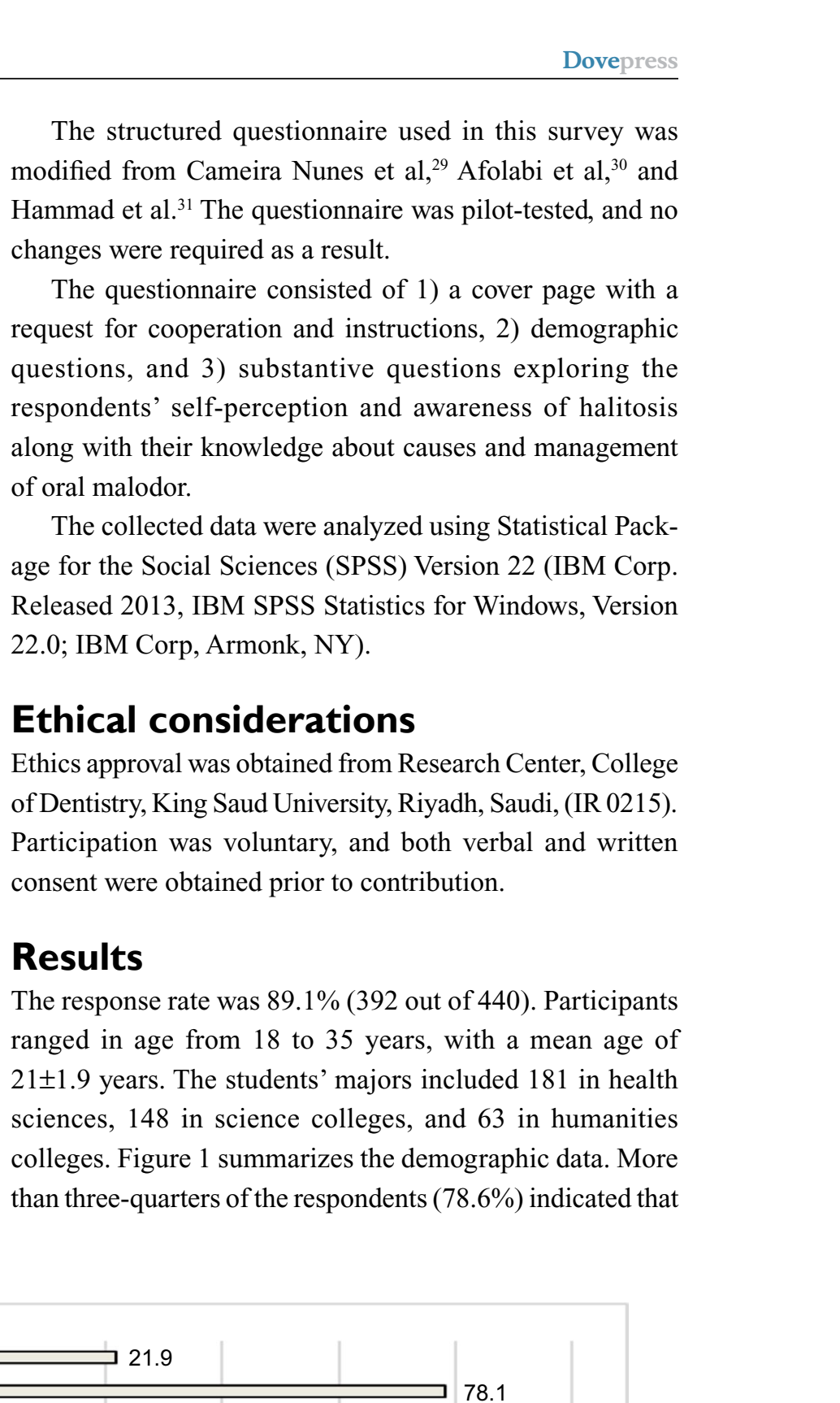

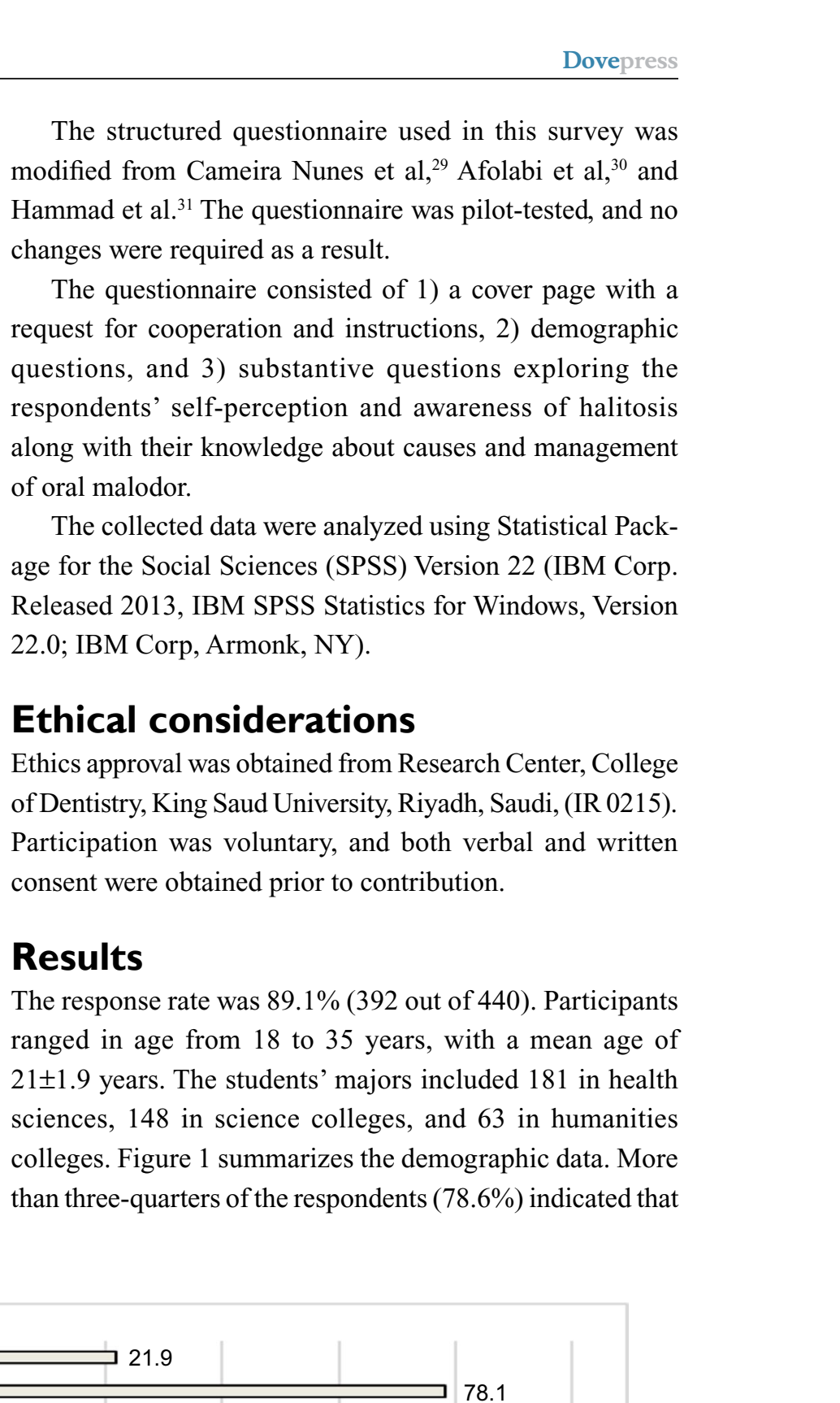

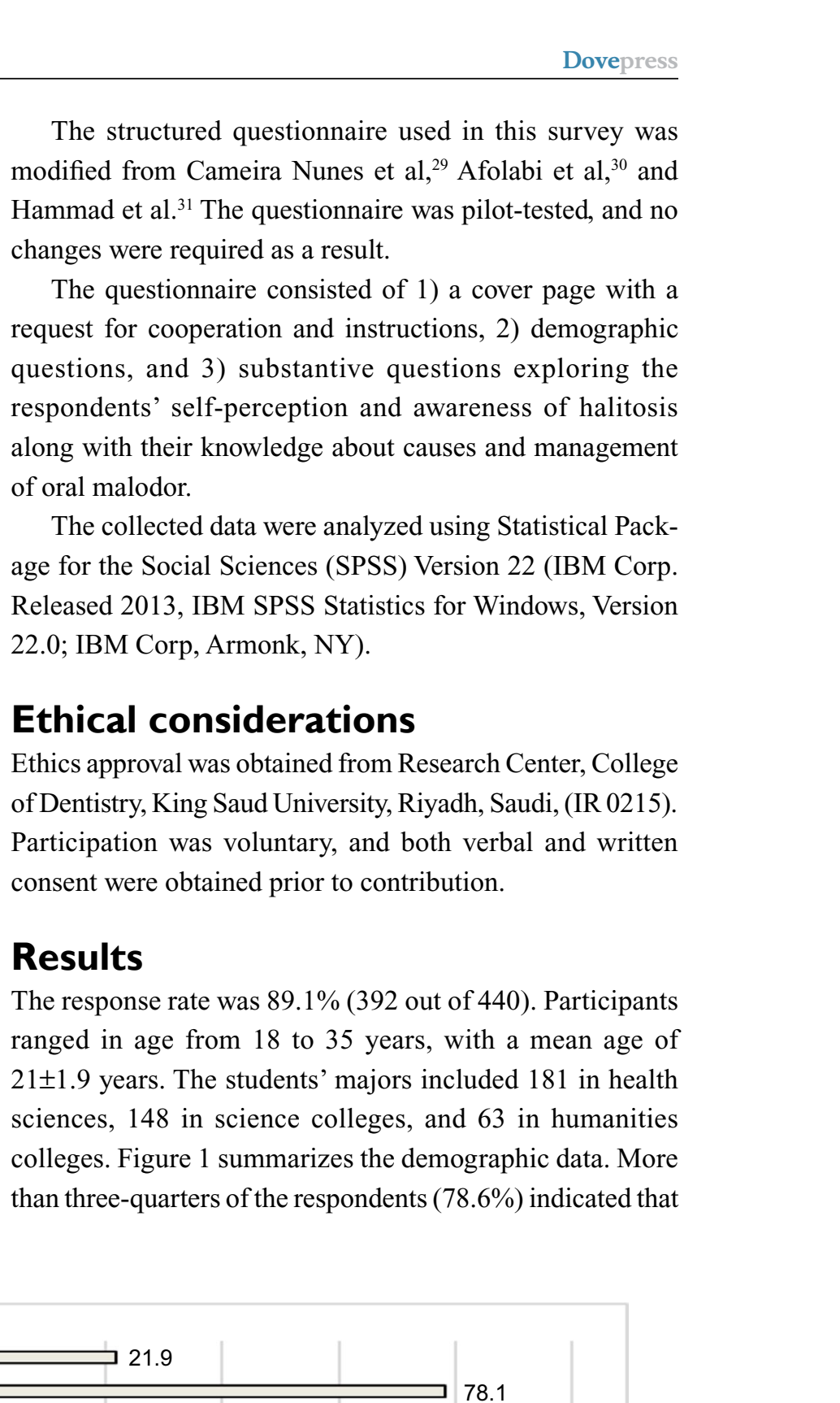

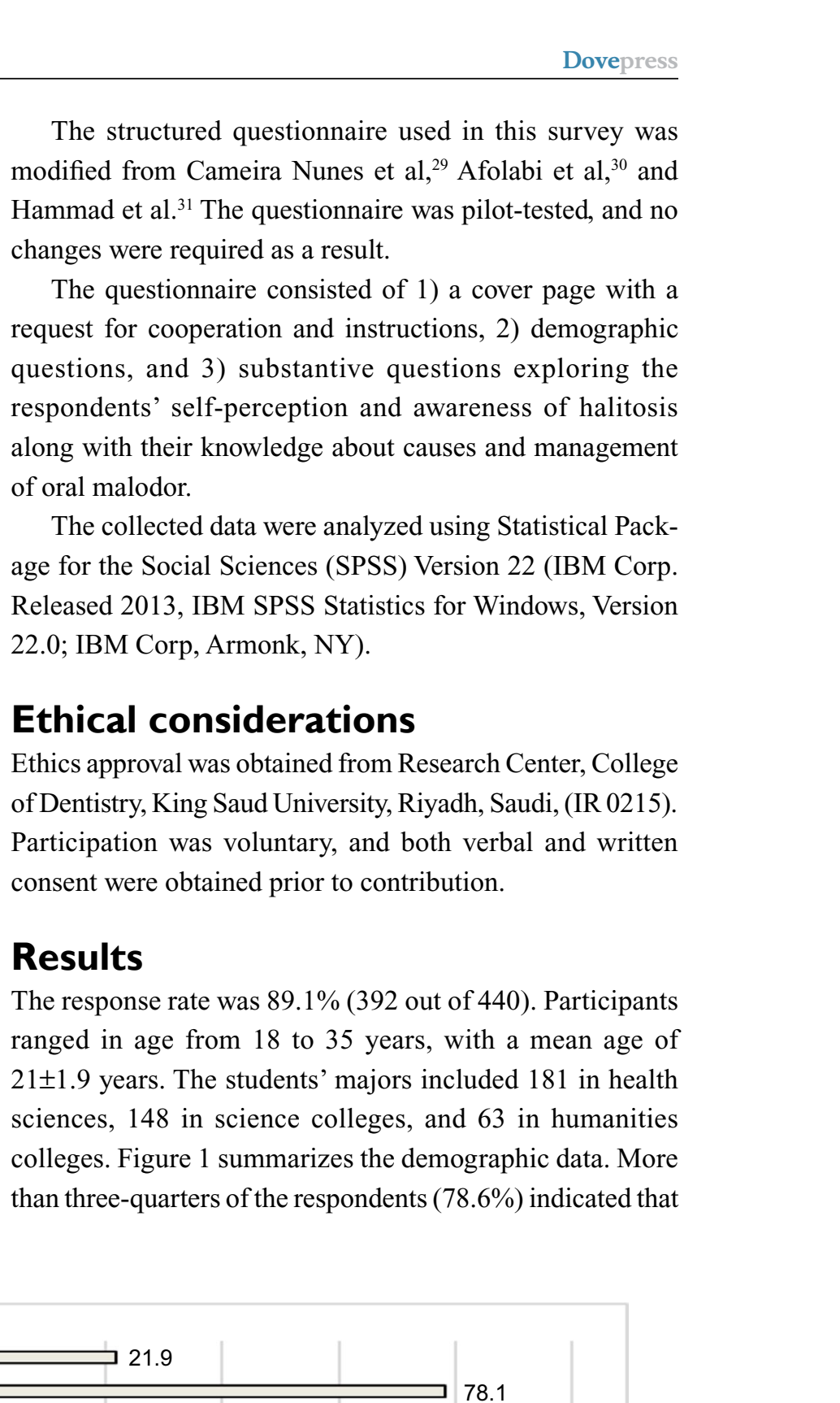

Have you ever noticed bad breath from your friends or colleagues?

How did you know that you have bad breath?

Do you suffer from halitosis?

Field of study (college)

Age (years)

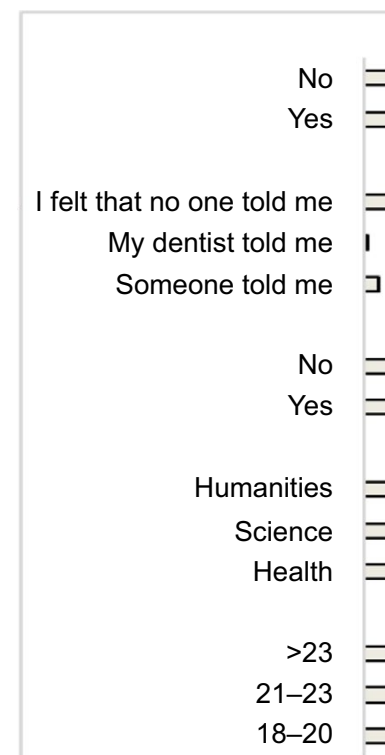

No

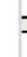
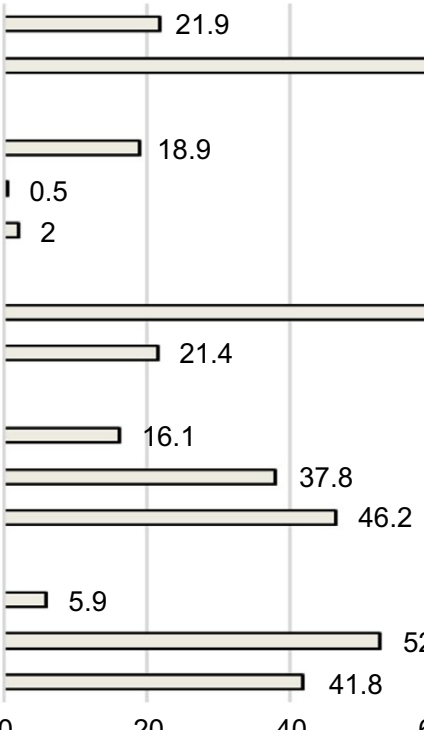

\section{(1)}

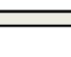

4

(n)

0
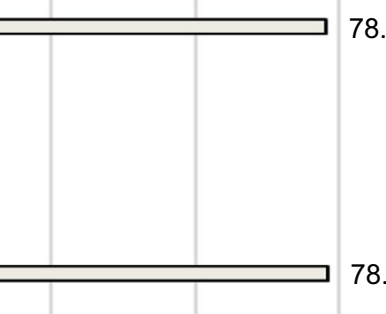
they did not suffer from halitosis. Most of the respondents who reported having halitosis (18.9\%) admitted to having discovered it on their own (Figure 1).

As for the primary origins of halitosis, $44.6 \%$ cited the stomach, followed by the periodontal pocket (37.5\%) and the tongue (34.4\%). A strong majority (78.1\%) agreed that an important cause of halitosis was not brushing one's teeth, followed by dry mouth (31.4\%), smoking (23.5\%), and ear, nose, and throat (ENT) diseases (21.9\%). Systemic diseases were cited as related to halitosis with the following frequency: gastrointestinal tract , $80.4 \%$; respiratory diseases, $15.6 \%$; and diabetes, $12.5 \%$. The results are presented in Table 1 . More than three-quarters of the sample $(77.0 \%)$ thought that bad breath can be managed through a self-care plan involving products such as mouthwash. Almost one-third of the sample (31.9\%) said that they would go to their dentist for help with this problem (Table 1).

A great majority of the respondents $(82.1 \%)$ said that they would not take any action if they noticed halitosis in their colleagues or friends; only $5.1 \%$ would advise a friend to go to the dentist or use other remedies. Nearly half of the sample $(47.2 \%)$ indicated that self-evaluation is the main way to detect bad breath, followed by smelling a tongue scraping (30.1\%) (Table 2).

Table I Summary of the sample responses to questionnaires

\begin{tabular}{|c|c|c|c|c|c|}
\hline \multirow[t]{2}{*}{ Variables } & \multirow[t]{2}{*}{ Factor } & \multicolumn{2}{|l|}{ Yes } & \multicolumn{2}{|l|}{ No } \\
\hline & & $\mathbf{n}$ & Percent & $\mathbf{n}$ & Percent \\
\hline \multirow[t]{6}{*}{ What is/are the origin of malodor? } & Gingival sulcus/periodontal pocket & 147 & 37.5 & 245 & 62.5 \\
\hline & Tongue coating & 135 & 34.4 & 257 & 65.6 \\
\hline & Stomach & 175 & 44.6 & 217 & 55.4 \\
\hline & Nasal cavity & 8 & 2.0 & 384 & 98.0 \\
\hline & I do not know & 24 & 6.1 & 368 & 93.9 \\
\hline & Others & 39 & 9.9 & 353 & 90.1 \\
\hline What is/are the local cause(s) & Alcohol & 44 & 11.2 & 348 & 88.8 \\
\hline \multirow[t]{5}{*}{ of malodor? } & Smoking & 92 & 23.5 & 300 & 76.5 \\
\hline & Dry mouth & 123 & 31.4 & 269 & 68.6 \\
\hline & ENT diseases & 86 & 21.9 & 306 & 78.1 \\
\hline & Not brushing teeth & 306 & 78. 1 & 86 & 21.9 \\
\hline & Other & 29 & 7.4 & 363 & 92.6 \\
\hline What is/are the systemic cause(s) & Gastrointestinal & 315 & 80.4 & 77 & 19.6 \\
\hline \multirow[t]{6}{*}{ of malodor? } & Hepatic & 30 & 7.7 & 362 & 92.3 \\
\hline & Renal & 9 & 2.3 & 383 & 97.7 \\
\hline & Respiratory & 61 & 15.6 & 331 & 84.4 \\
\hline & Obesity & 5 & 1.3 & 387 & 98.7 \\
\hline & Diabetes mellitus & 49 & 12.5 & 343 & 87.5 \\
\hline & Other & 6 & 1.5 & 386 & 98.5 \\
\hline How would you handle malodor if you & Go to the dentist & 125 & 31.9 & 267 & 68.1 \\
\hline \multirow[t]{4}{*}{ have it? } & Ask for advice from close people to you & 17 & 4.3 & 375 & 95.7 \\
\hline & Try to solve by myself (using mouthwash, chewing gums, etc.) & 302 & 77.0 & 90 & 23.0 \\
\hline & Take no action & 0 & 0 & 392 & 100.0 \\
\hline & Other & 3 & 0.8 & 389 & 99.2 \\
\hline What action would you take if you & Tell her/him and advise to go to the dentist & 20 & 5.1 & 372 & 94.9 \\
\hline \multirow[t]{3}{*}{ noticed malodor from a colleague? } & Tell her/him and advise to use mouthwash or chewing gum etc. & 39 & 9.9 & 353 & 90.1 \\
\hline & Would not tell her/him & 322 & 82.1 & 70 & 17.9 \\
\hline & Other & II & 2.8 & 381 & 97.2 \\
\hline \multirow[t]{6}{*}{ Methods of detecting malodor } & Self-evaluation & 185 & 47.2 & 207 & 52.8 \\
\hline & Feeling of bad taste & 62 & 15.8 & 330 & 84.2 \\
\hline & Smelling tongue scraping & 118 & 30.1 & 274 & 69.9 \\
\hline & Asking a confidant & 90 & 23.0 & 302 & 77.0 \\
\hline & I do not know & 36 & 9.2 & 356 & 90.8 \\
\hline & Other & 5 & 1.3 & 387 & 98.7 \\
\hline Health professional qualified to treat & Dentist & 323 & 82.4 & 69 & 17.6 \\
\hline \multirow[t]{3}{*}{ malodor } & ENT specialist & 20 & 5.1 & 372 & 94.9 \\
\hline & Gastroenterology specialist & 67 & 17.1 & 324 & 82.7 \\
\hline & Physician & 34 & 8.7 & 358 & 91.3 \\
\hline
\end{tabular}

Abbreviation: ENT, ear, nose, and throat. 
Table 2 Student's $t$-test of respondents' views of the causes and management of self-perceived halitosis

\begin{tabular}{|c|c|c|c|c|c|c|}
\hline \multicolumn{2}{|l|}{ Variables } & \multirow{2}{*}{\begin{tabular}{|l}
$\mathbf{N}$ \\
84 \\
\end{tabular}} & \multirow{2}{*}{\begin{tabular}{|l|} 
Mean \\
1.32 \\
\end{tabular}} & \multirow{2}{*}{\begin{tabular}{|l}
$\begin{array}{l}\text { Std. } \\
\text { deviation }\end{array}$ \\
0.470 \\
\end{tabular}} & \multirow{3}{*}{\begin{tabular}{|l}
$t$ \\
2.564
\end{tabular}} & \multirow{3}{*}{$\begin{array}{l}\text { Sig. } \\
\text { (2-tailed) } \\
0.011\end{array}$} \\
\hline \multirow{2}{*}{$\begin{array}{l}\text { What is/are the local cause(s) of malodor? } \\
\text { - Not brushing Teeth }\end{array}$} & Yes & & & & & \\
\hline & No & 308 & 1.19 & 0.394 & & \\
\hline \multirow{2}{*}{$\begin{array}{l}\text { Health professional qualified to treat malodor } \\
\text { - Dentist }\end{array}$} & Yes & 84 & 1.79 & 0.413 & \multirow[t]{2}{*}{2.331} & \multirow[t]{2}{*}{0.020} \\
\hline & No & 308 & 1.65 & 0.477 & & \\
\hline
\end{tabular}

Abbreviations: Std., standard; Sig., significant.

The respondents' knowledge about halitosis was analyzed statistically in relation to SPH, age, and field of study. The results of this analysis are summarized in Tables 1-3.

A significant difference was found between respondents with SPH and those without SPH in terms of their belief that the source of the bad breath is not brushing $(p=0.011)$ and their likelihood of visiting a dentist for help $(p=0.020)$. Individuals with SPH were less to consider teeth brushing and visiting a dentist for halitosis (Table 2).

An analysis of variance showed significant variation between age groups $(p=0.034)$ in self-perception of bad breath. A post hoc Tukey test showed that the 18-20 age group had significantly more perceptions of halitosis compared to those over age $23(p=0.028)$. The origin of halitosis was attributed to stomach problems significantly more often by respondents aged $21-23$ years $(p=0.033)$ than by those aged $18-20$ years. The youngest group (ie, those aged $18-20$ years) was less likely to believe that ENT diseases contributed to bad breath than those over $23(p=0.035)$. Treating halitosis by going to an ENT specialist was opposed significantly more often by the 21-23 age group than by other respondents ( $p=0.004)$ (Table 3).

The tongue was selected less often as a primary origin of bad breath by health science students $(p=0.000)$. In contrast, these students were more likely to identify dry mouth $(p=0.001)$ and diabetes $(p=0.000)$ as causes. The great majority of respondents $(94.9 \%)$ indicated unwillingness to tell a friend or colleague that he/she has bad breath and advise $\mathrm{him} /$ her to go to the dentist ( $p=0.008$ ). Finally, $84.2 \%$ agreed that a bad taste in the mouth is not a way to detect halitosis $(p=0.014)$ (Table 3).

\section{Discussion}

Bad breath is a common worldwide problem with substantial psychological and social implications, including a negative impact on marital relationships..$^{21,32}$ The worldwide prevalence of halitosis has been well established in many studies. ${ }^{2}$ Clinically, the presence of different bacterial species along with temperature and humidity conditions in the oral cavity can produce odorous compounds..$^{2,46}$ This study was conducted to assess the self-perception, knowledge, and awareness of halitosis among young, well-educated females. Its findings are important because halitosis is one of the most unattractive aspects of social interaction. ${ }^{33}$ In contrast to several studies, ${ }^{2,4,16,34}$ though similar to others, ${ }^{35-37}$ the rate of SPH was relatively low among the respondents in this investigation.

Age influences the self-perception of halitosis. One explanation for this pattern could be that younger people tend to be more vigilant and anxious about their health than middle-aged people. ${ }^{38,39}$ Furthermore, younger individuals tend to sense oral malodor more readily and to seek help with the problem.

Although Bornstein et $\mathrm{a}^{40}$ and Hammad et $\mathrm{a} \mathrm{l}^{31}$ reported a weak association between self-reported halitosis and organoleptic or VSC measurements, other reports indicated that self-perceived oral malodor is significantly associated with oral hygiene measures, tooth brushing, anxiety, lack of confidence in talking with others, social avoidance, and uncomfortable feelings around people. ${ }^{36,41}$ It has been also related to sinusitis and to cardiovascular and gastrointestinal tract diseases. ${ }^{36}$ Other studies have found connections between halitosis and tongue coating, strange intraoral taste, irregular dental visits, and deficient knowledge regarding halitosis management. ${ }^{19,41,42}$ Among the elderly, self-reported halitosis was linked to subjective oral dryness, tongue coating, inadequate oral hygiene practice, and the presence of dentures. ${ }^{37}$

In contrast to the findings of Alshehri, ${ }^{41}$ the participants in this study cited stomach problems most frequently as a main cause of bad breath, followed by periodontal diseases and tongue coating. This result could be explained by age differences, as the 21-23 age group especially held this view. It could also be related to the respondents' extent of knowledge, since individuals who were majoring in health sciences selected the tongue as the main source.

As in prior studies, most respondents agreed that not brushing is the main cause of having bad breath. ${ }^{21,41}$ In the literature, self-reported halitosis has been connected to insufficient oral hygiene and infrequent tooth brushing. ${ }^{16,37}$ Lack of knowledge about halitosis prevention among people with SPH has been also reported. ${ }^{3}$ Nonetheless, awareness and 
Table 3 Analysis of variance of sources and causes of SPH by age group and field of study

\begin{tabular}{|c|c|c|c|c|c|c|}
\hline Variables & & Sum of squares & $d f$ & Mean square & $\mathbf{F}$ & Sig. \\
\hline \multicolumn{7}{|c|}{ Analysis of variance of source and cause of self-perceived halitosis versus age group } \\
\hline \multirow[t]{3}{*}{ Do you suffer from bad breath odor? } & Between groups & 1.792 & 2 & 0.896 & 3.414 & 0.034 \\
\hline & Within groups & 102.126 & 389 & 0.263 & & \\
\hline & Total & 103.918 & 391 & & & \\
\hline \multirow{4}{*}{$\begin{array}{l}\text { What is/are the origin of malodor? } \\
\text { - Stomach }\end{array}$} & Between groups & 0.612 & 2 & 0.306 & 3.450 & 0.033 \\
\hline & & & & & & \\
\hline & Within groups & 34.508 & 389 & 0.089 & & \\
\hline & Total & 35.120 & 391 & & & \\
\hline \multirow{4}{*}{$\begin{array}{l}\text { What is/are the local cause(s) of oral malodor? } \\
\text { - ENT diseases }\end{array}$} & Between groups & 1.150 & 2 & 0.575 & 3.390 & 0.035 \\
\hline & & & & & & \\
\hline & Within groups & 65.983 & 389 & 0.170 & & \\
\hline & Total & 67.133 & 391 & & & \\
\hline \multirow{4}{*}{$\begin{array}{l}\text { Health professional qualified to treat oral malodor } \\
\text { - ENT specialist }\end{array}$} & Between groups & 0.535 & 2 & 0.268 & 5.642 & 0.004 \\
\hline & & & & & & \\
\hline & Within groups & 18.445 & 389 & 0.047 & & \\
\hline & Total & 18.980 & 391 & & & \\
\hline \multicolumn{7}{|l|}{$\begin{array}{l}\text { Analysis of variance of self-perceived halitosis versus } \\
\text { field of study }\end{array}$} \\
\hline \multirow{4}{*}{$\begin{array}{l}\text { What is/are the origin of oral malodor? } \\
\text { - Tongue }\end{array}$} & Between groups & 5.905 & 2 & 2.953 & 13.905 & 0.000 \\
\hline & & & & & & \\
\hline & Within groups & 82.602 & 389 & 0.212 & & \\
\hline & Total & 88.508 & 391 & & & \\
\hline \multirow{4}{*}{$\begin{array}{l}\text { What is/are the local cause(s) of oral malodor? } \\
\text { - Dry mouth }\end{array}$} & Between groups & 3.042 & 2 & 1.521 & 7.272 & 0.001 \\
\hline & & & & & & \\
\hline & Within groups & 81.364 & 389 & 0.209 & & \\
\hline & Total & 84.406 & 391 & & & \\
\hline \multirow{4}{*}{$\begin{array}{l}\text { What is/are the systemic cause(s) of oral malodor? } \\
\text { - Diabetes mellitus }\end{array}$} & Between groups & 3.101 & 2 & 1.550 & 15.164 & 0.000 \\
\hline & & & & & & \\
\hline & Within groups & 39.774 & 389 & 0.102 & & \\
\hline & Total & 42.875 & 391 & & & \\
\hline \multirow{4}{*}{$\begin{array}{l}\text { What action would you take if you noticed oral malodor } \\
\text { from a colleague? } \\
\text { - You tell her/him and advise her/him to go to the dentist }\end{array}$} & Between groups & 0.471 & 2 & 0.235 & 4.946 & 0.008 \\
\hline & & & & & & \\
\hline & Within groups & 18.509 & 389 & 0.048 & & \\
\hline & Total & 18.980 & 391 & & & \\
\hline \multirow{4}{*}{$\begin{array}{l}\text { What are the methods of detecting oral malodor? } \\
\text { - Feeling of bad taste }\end{array}$} & Between groups & 1.133 & 2 & 0.567 & 4.317 & 0.014 \\
\hline & & & & & & \\
\hline & Within groups & 51.061 & 389 & 0.131 & & \\
\hline & Total & 52.194 & 391 & & & \\
\hline
\end{tabular}

Abbreviations: $d f$, degree of freedom; ENT, ear nose throat; Sig., significant; SPH, self-perceived halitosis.

concern regarding halitosis are reported to result in better extraoral self-care practices. ${ }^{19,24}$

As in the present study, Sedky ${ }^{21}$ reported that a high percentage of respondents identified dentists as the best professionals to treat bad breath, in contrast to a Portuguese study in which gastroenterologists were most frequently selected..$^{29}$ Our investigation determined that people who did not have SPH were more likely to assume that tooth brushing is a main cause of the problem and to believe that home remedies are the best way to manage malodor. These results may indicate lack of proper knowledge among university students, particularly those not in health sciences field.

Our investigation revealed poor knowledge of the extraoral factors associated with halitosis other than gastrointestinal tract disorders. It has been shown that halitosis could be associated with or caused by various factors such as chronic sinusitis, upper respiratory tract infections, diabetes, older age, being female, and lower education and socioeconomic status. ${ }^{16,25,36,43}$ Improper breathing could also contribute to this problem via mouth dryness. ${ }^{43}$ Further emphasis should be placed on the nonoral causes of halitosis, such as ENT and pulmonary pathology metabolic disorders along with some medications.

This study found that a very low percentage of respondents identified the effect of alcohol consumption on bad breath, which is probably because of religious and cultural matters that limit the prevalence of alcohol intake in Saudi society. 
In agreement with previous research by Hammad et $\mathrm{al}^{31}$ and Eldarrat et al, ${ }^{28}$ this study found that most respondents preferred solving halitosis problems through such methods as mouthwash, chewing gum, and traditional medicine rather than by going to the dentist. This preference probably reflects lack of awareness of etiology and treatment strategies. Oral mouthwashes containing essential oils, herbal extracts, and peppermint possess some antimicrobial effectiveness while not leading to resistant microorganism strains or causing allergic reactions. Thus, persons affected by halitosis might consider synthetic mouthwashes a safe choice with competitive results. ${ }^{44-46}$ Likewise, chewing gum has been shown to decrease the presence of VSCs, thus improving the perception of halitosis by the patient and others. ${ }^{47}$ It can also effectively inhibit cysteine-induced odor. ${ }^{48}$

In contrast to Nigerian health care workers or students, who were willing to ask a close friend's opinion, ${ }^{30}$ nearly half of the respondents in the present study (47.2\%) agreed that self-evaluation is the best method to detect halitosis. The gold standard for halitosis diagnosis is the organoleptic scoring scale. A more objective method, however, involves analyzing breath samples by gas chromatography or portable VSC analyzers. ${ }^{43}$ More recently, the Bionote multisensor system and OralChroma have been found useful in assessing initial halitosis conditions and in aiding its mitigation during treatment. This sensor-based system mimics the nose, tongue, and eyes, and two of the present authors found that it can be used to analyze the volatile and liquid parts of a sample. ${ }^{49}$

The vast majority of respondents were unwilling to tell a friend or colleague about his/her bad breath, and very few would recommend, upon noticing a friend's oral malodor, that he/she goes to the dentist. These responses may reflect social perceptions about the psychological effects of halitosis. On the other hand, they also imply increased responsibility for professionals who have the opportunity to identify and address this problem in their patients. They also indicate the importance of covering such issues in dental training curricula. Akaji et al ${ }^{50}$ found that oral health care professionals are the first specialists consulted by most affected patients.

Halitosis has been shown to be a very uncommon reason for patients to visit a dental clinic. ${ }^{51}$ Thus, its diagnosis and management should be incorporated within comprehensive dental care.$^{52}$ Professional training to enhance the communication skills of oral health care professionals is crucial, because communicating sensitively with patients who are unaware of the existence or nature of their problem may play an important role in enabling patients to accept this information without undesirable side effects. ${ }^{53}$ It is also useful to provide guidelines on the screening, diagnosis, and treatment of malodor, aimed at stimulating optimal oral health care. ${ }^{54}$

\section{Conclusion}

The present study found a relatively low rate of self-reported halitosis, but a far greater proportion indicated that malodor was a problem for people around them. Most respondents indicated that they would address bad breath by masking rather than by treating the cause. There is a general lack of knowledge about oral malodor in all its aspects. Thus, greater public awareness and education should be encouraged. Dentists' role in informing and educating their patients concerning oral malodor should be emphasized, and dental students should be trained to address this issue effectively.

\section{Author contribution}

Azizah Bin Mubayrik wrote the original draft and contributed to conceptualization, methodology, project administration, resources, supervision, and formal analysis.

Emad M Al Hadlaq was involved with the results, statistics, and formal analysis.

Rana Al Hamdan and Hamad AlBagieh were committed to validation, review writing, and editing of the draft.

Dan AlAhmed, Hend Jaddoh, Mawadh Demyati, and Rawan Abu Shryei investigated, collected data, and entered the data for statistics.

All authors contributed toward data analysis, drafting and critically revising the paper and agree to be accountable for all aspects of the work.

\section{Disclosure}

The authors report no conflicts of interests in this work.

\section{References}

1. Kukkamalla D, Cornelio D, Mahalinga Bhat D, Avadhani D, Goyal D. HALITOSIS - A Social Malady. IOSR-JDMS. 2014;13(5):55-61.

2. Rösing CK, Loesche W. Halitosis: an overview of epidemiology, etiology and clinical management. Braz Oral Res. 2011;25(5):466-471.

3. Azodo C, Umoh A. Self-perceived oral malodour among periodontal patients: prevalence and associated factors. Int J Med Biomed Res. 2013;2(2):125-132.

4. Ratclif R. Current concepts in the causes and treatment of halitosis. Pract Hygine. 1997:47-53.

5. Lenton P, Majerus G, Bakdash B. Counseling and Treating Bad Breath Patients: A Step-By-Step Approach | Continuing Education Course | dentalcare.com Introduction | DentalCare.com. Dentalcarecom; 2016. Available from: http://www.dentalcare.com/en-US/dental-education/ continuing-education/ce130/ce130.aspx. Accessed October 1, 2016.

6. Zalewska A, Zatoński M, Jabłonka-Strom A, Paradowska A, Kawala B, Litwin A. Halitosis - a common medical and social problem. A review on pathology, diagnosis and treatment. Acta gastro-enterologica Belgica. 2012;75(3):300-309.

7. Newman M, Takei H, Klokkevold P, Carranza F. Carranza's Clinical Periodontology. London: Elsevier Health Sciences; 2014. 
8. Kapoor U, Sharma G, Juneja M, Nagpal A. Halitosis: current concepts on etiology, diagnosis and management. Eur J Dent. 2016;10(2):292.

9. Suzuki N, Yoneda M, Naito T, Iwamoto T, Hirofuji T. Relationship between halitosis and psychologic status. Oral Surg Oral Med Oral Pathol Oral Radiol Endod. 2008;106(4):542-547.

10. Yaegaki K, Coil JM. Examination, classification, and treatment of halitosis; clinical perspectives. J Can Dent Assoc. 2000;66(5):257-261.

11. Falcão D, Vieira C, Batista de Amorim RF. Breaking paradigms: a new definition for halitosis in the context of pseudo-halitosis and halitophobia. J Breath Res. 2012;6(1):017105.

12. Yamunadevi A, Selvamani M, Mohan Kumar K, Basandi P, Madhushankari G. Halitosis - An overview: Part-I - Classification, etiology, and pathophysiology of halitosis. J Pharm Bioallied Sci. 2015;7 (Suppl 2): S339-S343.

13. Zürcher A, Laine M, Filippi A. Diagnosis, prevalence, and treatment of halitosis. Curr Oral Health Rep. 2014;1(4):279-285.

14. Van den Broek A, Feenstra L, de Baat C. A review of the current literature on aetiology and measurement methods of halitosis. $J$ Dent. 2007;35(8):627-635.

15. Coil J, Yaegaki K, Matsuo T, Miyazaki H. Treatment Needs (TN) and practical remedies for halitosis. Int Dent J. 2002;52 (Suppl 3):187-191.

16. Al-Ansari J, Boodai H, Al-Sumait N, Al-Khabbaz A, Al-Shammari K, Salako N. Factors associated with self-reported halitosis in Kuwaiti patients. J Dent. 2006;34(7):444-449.

17. Arora L, Sharma A. A study to find out the dental and associated psychosocial factors in patients of halitosis. Delhi Psychiat J. 2012; 15(1):122-129.

18. Troger B, Almeida Jr H, Duquia R. Emotional impact of halitosis. Trends Psychiat Psychother. 2014;36(4):219-221.

19. Azodo C, Odai C, Onyeagba M. Does concern about halitosis influence individual's oral hygiene practices? Niger Med J. 2011;52(4):254.

20. Adewole R, Eweka O, Agbelusi G. A review of knowledge, diagnosis and treatment of halitosis among nigerian dentists - a pilot study. Oral Biol Dent. 2014;2(1):6.

21. Sedky NA. Perceived impact of halitosis on individual's social life and marital relationship in Qassim Province, KSA. J Am Sci. 2015;11(3).

22. Cherreka M. The Critical Role of Youth in Global Development: Issue Brief. Wahington, DC: International Center for Research on Women; 2001

23. Almas K, Al-Hawish A, Al-Khamis W. Oral hygiene practices, smoking habit, and self-perceived oral malodor among dental students. J Contemp Dent Pract. 2003;4(4):77-90.

24. Setia S, Pannu P, Gambhir R, Galhotra V, Ahluwalia P, Sofat A. Correlation of oral hygiene practices, smoking and oral health conditions with self perceived halitosis amongst undergraduate dental students. $J$ Nat Sci Biol Med. 2014;5(1):67.

25. Ashwath B, Vijayalakshmi R, Malini S. Self-perceived halitosis and oral hygiene habits among undergraduate dental students. J Indian Soc Periodontol. 2014;18(3):357.

26. Al-Atrooshi BA, Al-Rawi AS. Oral halitosis and oral hygiene practices among dental students. Bagh Coll Dent. 2007;19(1):72-76.

27. Hasan G. Oral hygiene practices and self - perceived halitosis among dental students. J Bagh College Dentistry. 2014;26(3):58-62.

28. Eldarrat A, Alkhabuli J, Malik A. The prevalence of self-reported halitosis and oral hygiene practices among libyan students and office workers. Libyan J Med. 2008;3(4):170-176.

29. Cameira Nunes J, Martínez-Sahuquillo Á, Cameira M, Dias Marques H. Halitosis: are dentists being prepared for this challenge? - A questionnaire survey in a dental school. Revista Portuguesa de Estomatología Medicina Dentária e Cirugia Maxilofacial. 2011;52(3):142-146.

30. Afolabi AO, Ogundipe OK, Eleckwachi G. Halitosis (bad breath): an assessment of the awareness and knowledge of health providers in a Nigerian community. Sudan Med J. 2009;45:43-48. Available from: http://www.smj.eg.net/journals/pdf/229.pdf.

31. Hammad M, Darwazeh A, Al-Waeli H, Tarakji B, Alhadithy T. Prevalence and awareness of halitosis in a sample of Jordanian population. J Int Soc Prevent Community Dent. 2014;4 (Suppl 3):S178-S186.
32. Mineoka T, Awano S, Yoshida A, Soh I, Hamasaki T, Ansai T. Survey regarding knowledge and awareness of halitosis in community-dwelling young Japanese women. $J$ Dent Health. 2011;61:282-287.

33. de Jongh A, van Wijk A, Horstman M, de Baat C. Attitudes towards individuals with halitosis: an online cross sectional survey of the Dutch general population. $B D J .2014 ; 216(4)$ :E8

34. Bornstein M, Stocker B, Seemann R, Bürgin W, Lussi A. Prevalence of halitosis in young male adults: a study in Swiss army recruits comparing self-reported and clinical data. J Periodontol. 2009;80(1):24-31.

35. Miyazaki H, Sakao S, KatohY. Correlation between volatile sulphur compounds (VSCs) and certain oral health measurements in the general population. J Periodontol. 1995;66:679-684.

36. Alsadhan S, Darwish A. Non-oral factors associated with self-reported halitosis among adults living in Riyadh, Saudi Arabia. OHDM. 2015;14(1):58-61.

37. Nalcaci R, Baran I. Factors associated with self-reported halitosis (SRH) and perceived taste disturbance (PTD) in elderly. Arch Gerontol Geriat. 2008;46(3):307-316.

38. McCrae RR, Bartone PT, Costa PT. Age, anxiety and self-reported health. Int J Aging Hum Dev. 1976;7:49-58.

39. Alzoubi FQ, Karasneh JA, Daamseh NM. Relationship of psychological abd oral health statuses with self-perceived halitosis in a Jordanian population: a cross-sectional study. BMC Oral Health. 2015;15;89.

40. Bornstein M, Kislig K, Brun Hoti B, Seemann R, Lussi A. Prevalence of halitosis in the population of the city of Bern, Switzerland: a study comparing self-reported and clinical data. Eur J Oral Sci. 2009;117(3):261-267.

41. Alshehri F. Knowledge and attitude of Saudi individuals toward selfperceived halitosis. Saudi J Dent Res. 2016;7(2):91-95.

42. Kameyama A, Ishii K, Tomita S, et al. Correlations between perceived oral malodor levels and self-reported oral complaints. Int $J$ Dent. 2015;2015:1-6.

43. Bollen CM, Beikler T. Halitosis: the multidisciplinary approach. Int $J$ Oral Sci. 2012;4(2):55-63.

44. Rostoka D, Kroica J, Iriste V, Reunis A, Kuznetsova V, Teibe U. Treatment of halitosis with mouth rinsing agents containing essential oils. Stomatologiia (Mosk). 2012;91(3):27-34.

45. Jameel RA, Khan SS, Kamaruddin MF, et al. Is synthetic mouthwash the final choice to treat oral malodour? J Coll Physicians Surg Pak. 2014;24(10):757-762.

46. Haghgoo R, Abbasi F. Evaluation of the use of peppermint mouth rinse for halitosis by girls studying in Tehran high schools. J Int Soc Prev Communnity Dent. 2013;3(1):29-31.

47. De Luca-Monasterios F, Chimenos-Kustner E, Lopez-Lopez J. Effect of chewing gum on halitosis. Med Clin (Barc). 2014;143(2):64-67.

48. Shiyao L, Yamei X, Deyu H. Anti-halitosis effect of suger-free chewing gum. Hua Xi Kou Qiang Yi Xue Za Zhi. 2015;33(2):166-168.

49. Marchetti E, Tecco S, Santonico M, et al. Multi-sensor approach for the monitoring of halitosis treatment via lactobacillus brevis (CD2)containing lozanges-a randomized, double-blind placebo-controlled clinical trial. Sensors (Basel). 2015;15(8):19583-19596.

50. Akaji EA, Folaranmi N, Ashiwaju O. Halitosis: a review of the literature on its prevalence, impact and control. Oral Health Prev Dent. 2014;12(4):297-304.

51. Ahmad MS, Al-Harbi KM. Behaviors and management of the dental problems by the residents of Madinah, Saudi Arabia. J Contemp Dent Pract. 2015;16(10):783-787.

52. Aimetti M, Perotto S, Castiglione A, Ercoli E, Romano F. Prevelance estimation of halitosis and its association with oral health-related parameters in an adult population of a city in north Italy. J Clin Periodontol. 2015;42(12):1105-1114.

53. Nardi GM, Forabosco A, Forabosco G, Musciotoo A, Campisi G, Grandi T. Halitosis: a stomatological and psychological issue. Minerva Stomatol. 2009;58(9):435-444.

54. Buunk-Werkhoven YA, Buls JG, Osinga E, Bruers JJ. Diagnosis and treatment of patients with halitosis by dental hygienists and dentists in the Netherlands. Int Dent J. 2015;65(2):65-70. 


\section{Publish your work in this journal}

Clinical, Cosmetic and Investigational Dentistry is an international, peer-reviewed, open access, online journal focusing on the latest clinical and experimental research in dentistry with specific emphasis on cosmetic interventions. Innovative developments in dental materials, techniques and devices that improve outcomes and patient satisfac- tion and preference will be highlighted. The manuscript management system is completely online and includes a very quick and fair peerreview system, which is all easy to use. Visit http://www.dovepress. com/testimonials.php to read real quotes from published authors.

Submit your manuscript here: https://www.dovepress.com/clinical-cosmetic-and-investigational-dentistry-journal 